\title{
ipen
}

AUTARQUIA ASSOCIADA À UNIVERSIDADE DE SÃO PAULO

\section{PROCESSO DE CLARIFICAÇÃO DE CALDO DE CANA-DE-AÇÚCAR APLICANDO ELÉTRONS ACELERADOS}

ROBERTA BERGAMIN LIMA

Dissertação apresentada como parte
dos requisitos para obtenção do Grau
de Mestre em Ciências na Área
de Tecnologia Nuclear - Aplicações
Orientador:
Prof. Dr. Valter Arthur 


\section{INSTITUTO DE PESQUISAS ENERGÉTICAS E NUCLEARES AUTARQUIA ASSOCIADA À UNIVERSIDADE DE SÃO PAULO}

\section{Processo de clarificação do caldo de cana-de-açúcar aplicando elétrons acelerados}

\section{Roberta Bergamin Lima}

Dissertação apresentada como parte dos requisitos para obtenção do Grau de Mestre em Ciências na Área de Tecnologia Nuclear - Aplicações

Orientador:

Prof. Dr. Valter Arthur 
Dedico este trabalho a minha mãe Dalva e a Deus. 


\section{AGRADECIMENTOS}

Agradeço a Deus por iluminar sempre meu caminho e pensamentos, me dando a oportunidade de desenvolver este trabalho com saúde e sabedoria.

À minha mãe Dalva pelo apoio, paciência, amor, força e atenção dedicados ao logo da minha vida e durante toda a execução deste trabalho.

Aos familiares em especial aos meus padrinhos e prima que me deram apoio, incentivo e atenção.

Ao Prof. Dr. Valter Arthur, meu orientador, pela oportunidade e por acreditar nesse trabalho, agradeço pelas dicas, sugestões, criticas.

Ao Prof. Dr. Antonio Sampaio Baptista e, em especial, ao Prof. Dr. Claudio Lima de Aguiar por todo material, conhecimento, ensinamentos, além da estrutura cedida, sem os quais o desenvolvimento deste trabalho não teria sido possível.

Agradeço ao meu namorado Tiago, pela paciência, incentivo, otimismo e companhia nas horas boas e ruins, durante todo o período de desenvolvimento deste trabalho.

Aos técnicos, estagiários e pós-graduandos do laboratório de Açúcar e Álcool da ESALQ pela contribuição ativa, pelas dicas, sugestões e ajuda.

Ao Grupo de Pesquisa Hugot-Bioenergia da ESALQ, pelas discussões, pelo apoio, ajuda e por compartilhar conhecimentos, sabedoria e trabalhos.

Aos meus amigos que estiveram sempre do meu lado, me apoiando mesmo que a distância, me incentivando e motivando nas horas difíceis, e compartilhando as horas de alegrias com muitas risadas.

Ao Programa de Pós-Graduação de Ciências e Tecnologia Nuclear Aplicações do IPEN pela oportunidade concedida.

Ao CNPq e à FAPESP pela bolsa e auxilio concedidos durante o desenvolvimento desta pesquisa. 


\title{
PROCESSO DE CLARIFICAÇÃO DO CALDO DE CANA-DE- AÇÚCAR APLICANDO ELÉTRONS ACELERADOS
}

\author{
ROBERTA BERGAMIN LIMA
}

\begin{abstract}
RESUMO
O caldo de cana-de-açúcar é um líquido opaco, viscoso, de cor amarelada esverdeada, de composição química complexa e variável, é utilizado para produção de cachaça, rapadura, álcool e principalmente açúcar. Em sua composição possui além de açúcares uma série de compostos que conferem cor e que pode interferir na cor do produto final gerado, sendo que dentre estes compostos podemos citar a clorofila, compostos fenólicos e flavonoides. Para produção de um açúcar de boa qualidade e aceitação comercial, o caldo passa pelo processo de sulfitação, que promove a redução da cor do caldo através do contato deste com o anidrido sulfuroso $\left(\mathrm{SO}_{2}\right)$, gerando um açúcar mais branco. No entanto, este açúcar por obter resíduos de enxofre, sofre restrições do mercado externo, o que vem incentivando o desenvolvimento de diversas técnicas alternativas de clarificação a fim de se produzir um açúcar mais branco e que atenda as exigências do mercado externo. Contudo, o presente trabalho avaliou o efeito da radiação por elétrons acelerados em caldo de cana-de-açúcar, comparando-os a testes preliminares realizados com caldo de cana-de-açúcar tratados com irradiação gama. As amostras foram irradiadas nas doses de 5, $10 \mathrm{e}$ $20 \mathrm{kGy}$ em ambos os tipos de radiação e foram comparadas com uma amostra controle in natura. Os resultados mostraram que houve um aumento significativo $(p<0,05)$ dos compostos fenólicos em ambos os tratamentos, provavelmente por que ao sofrer irradiação os ácidos fenólicos se tornam mais disponíveis na matriz. Observou-se ainda aumento dos níveis de açúcares redutores (glicose e frutose) tanto para as amostras irradiadas com radiação gama como para feixe de elétrons, fato verificado por análises cromatográficas quantitativas realizadas no caldo de cana-de-açúcar tratado com feixe de elétrons. Foi ainda observado que embora tenha ocorrido algumas alterações significativas $(p<0,05)$ quanto aos
\end{abstract}


parâmetros, que caracterizam o perfil do caldo, avaliados com Brix, pH, acidez total titulável, o trabalho manteve seu propósito de redução da cor ICUMSA do caldo de cana-de-açúcar em ambos os tratamentos sendo que essa redução representou aproximadamente $49 \%$ da amostra controle em relação a dose irradiada a $20 \mathrm{kGy}$, para feixe de elétrons e cerca de $30 \%$ para amostras irradiadas em fonte de cobalto-60. Mostrando que ambas as técnicas são eficazes na redução da cor do caldo de cana-de-açúcar, sendo que o método de irradiação por acelerador de elétrons apresenta vantagens em relação à irradiação gama além de obter maior índice de redução da cor, é o método de maior produção $\left(\mathrm{m}^{3} / \mathrm{h}\right)$ e mais seguro, segundo as regras de proteção radiológica. 


\title{
SUGARCANE JUICE CLARIFICATION APPLYING ELECTRON BEAM TECHNOLOGY
}

\author{
ROBERTA BERGAMIN LIMA
}

\begin{abstract}
The sugar cane juice is a liquid opaque, viscous, yellowish green, its chemical composition is complex and variable, is used for the production of spirit, molasses, alcohol, and mainly sugar. In its composition the sugar cane juice has a series of compounds as sugars and many others compounds which produces color and can interfere in the color of the final product produced, and among these we can mention the chlorophyll, phenolic compounds and flavanoids. To produce a sugar of good commercial quality and acceptability the sugar cane juice pass to the process of sulfitation, which promotes the reduction of color of the juice by its contact with the $\mathrm{SO}_{2}$, making a sugar whiter. However, these sugars that have residue of sulfur suffer some restrictions on the foreign market. In this sense many techniques has been discussed, to looking for to produce a white sugar and that respect the requirements of the foreign markets. Although, this work evaluated the effect of radiation of electron beam in a sugar cane juice and compared this results with a preliminary tests with sugar cane juice treated with gamma irradiation. The samples were radiated at 5, 10 and $20 \mathrm{kGy}$ doses in both of irradiation and compared a sample (control) without treatment. The results showed a significant increase $(p<0.05)$ of phenolic compounds, in both treatments, probably because the radiation of sugar cane juice become phenolic acids more available in the juice. We also observed increased levels of reducing sugars (glucose and fructose) for the samples irradiated with gamma irradiation and for electron beam, a fact verified by quantitative chromatographic analyzes performed in the sugar cane juice treated with electron beam. Even that we observe that these treatments although has shown some significant changes to the parameters that characterizing the profile of the juice like Brix, $\mathrm{pH}$, titratable acidity, was able to reduce de color ICUMSA of the sugar cane juice in both of treatments with
\end{abstract}


irradiation. By electron beam irradiation, the sugarcane juice reduce about $49 \%$ its color, compared the control and the sample that receive dose of $20 \mathrm{kGy}$, and the gamma irradiation the juice reduced about $30 \%$ color the control compared with samples irradiated in $20 \mathrm{kGy}$. These results show us that both techniques are effective in reducing the color ICUMSA of the sugar cane juice, and the method of irradiation by electron accelerator has advantages in addition to gamma irradiation because also cause greater reduction color, is the method of higher production $\left(\mathrm{m}^{3} / \mathrm{h}\right)$ and safer, according to the rules of radiological protection. 


\section{SUMÁRIO}

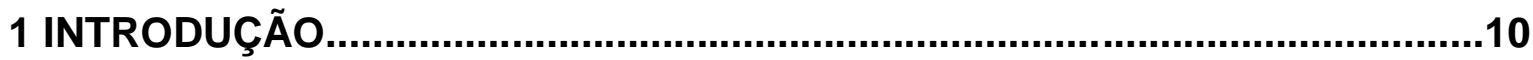

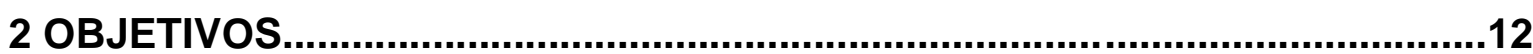

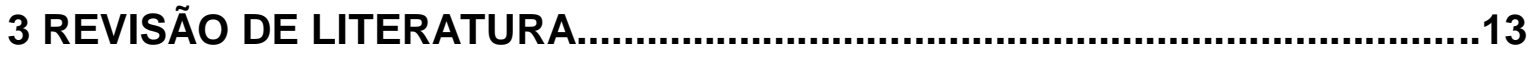

3.1 Cana-de-açúcar e posição no mercado.....................................................13

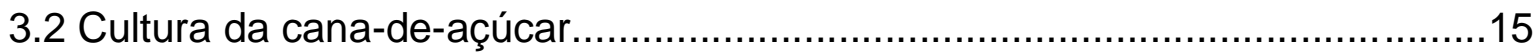

3.3 Caldo de cana-de-açúcar e sua composição..................................................16

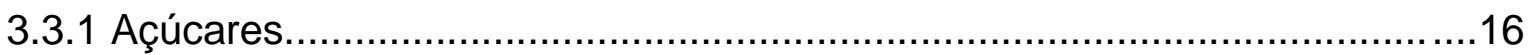

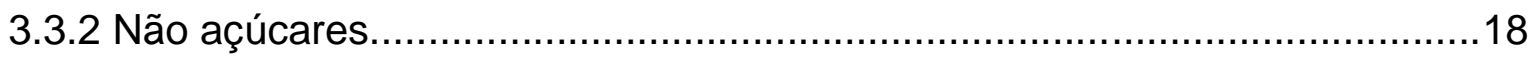

3.4 Processos de formação de compostos coloridos em caldo de cana-de-

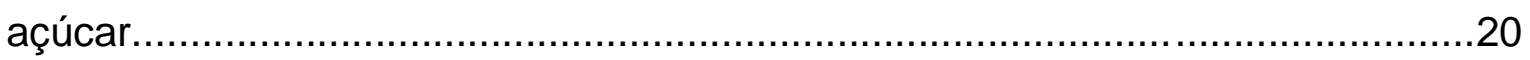

3.5 Tratamento do caldo de cana-de-açúcar.................................................22

3.5.1 Colheita, preparo, extração e peneiragem do caldo de cana-de-açúcar......22

3.5.2 Clarificação do caldo de cana-de-açúcar....................................................24

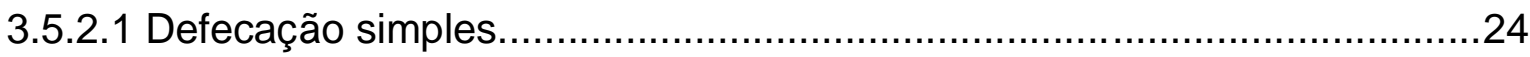

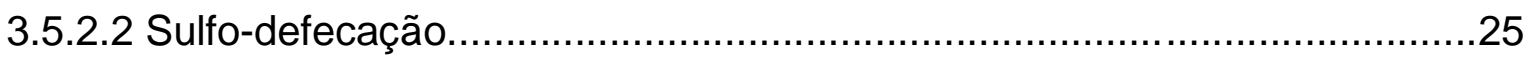

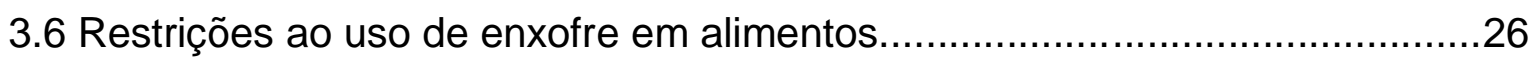

3.7 Processos ionizantes na clarificação do caldo de cana-de-açúcar...................28

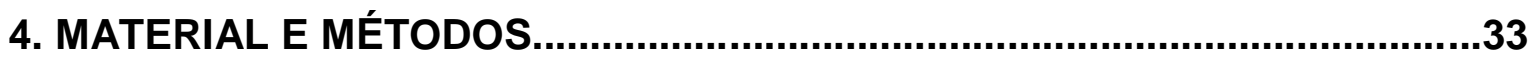

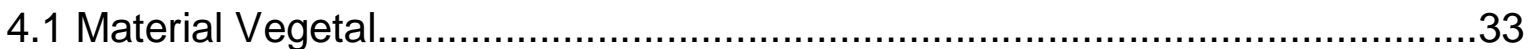

4.2 Ensaios de clarificação com irradiação em acelerador de elétrons..................33

4.3 Análises químicas do perfil composicional do caldo de cana-de-açúcar..........34

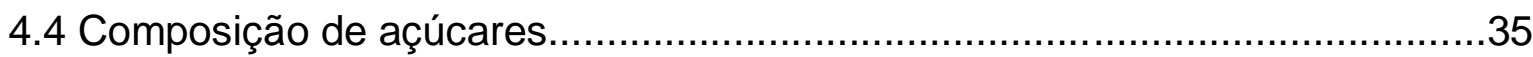

4.5 Determinação de compostos fenólicos e flavonoides......................................36

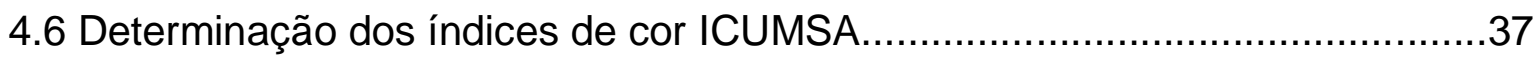

4.7 Análise cromatográfica de açúcares no caldo de cana-de-açúcar...................37

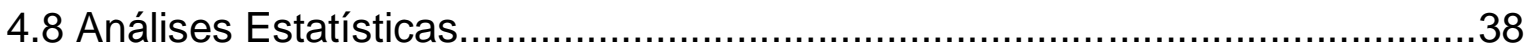




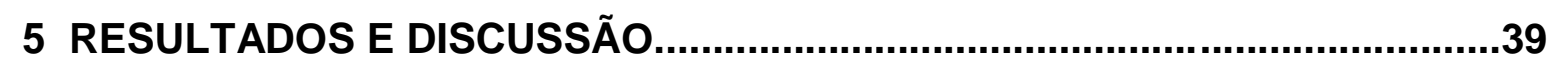

5.1 Perfil composicional do caldo de cana-de-açúcar..........................................39

5.2 Composição de açúcares no caldo de cana-de açúcar...................................41

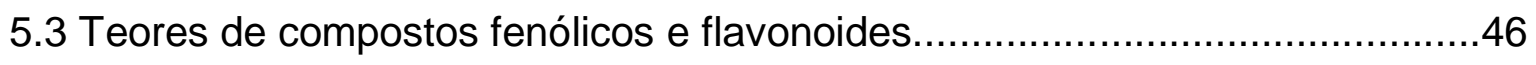

5.4 Avaliação da cor ICUMSA do caldo de cana-de-açúcar ................................48

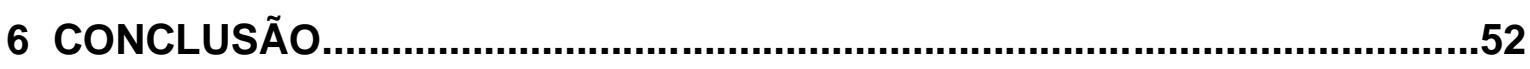

7 REFERÊNCIAS BIBLIOGRÁFICAS .......................................................53 


\section{INTRODUÇÃO}

A cana-de-açúcar (Saccharum spp.) é uma das maiores e mais antigas culturas agrícolas exploradas no Brasil, assumindo grande importância sócioeconômica, segundo levantamento da CONAB (2010). A partir dos anos 70, passou por importante transformação, deixando de ser exclusivamente voltado para o setor de alimentos, para destinar-se ao setor energético (WAACK e NEVES, 1998). É uma cultura de grande versatilidade sendo que; a partir do bagaço pode-se obter papel, ração, adubo ou combustível; a partir das folhas, cobertura morta ou ração animal e ainda se pode obter a partir do caldo de canade-açúcar o açúcar, cachaça, etanol, rapadura (VASCONCELOS, 2002). O caldo da cana-de-açúcar é um líquido viscoso, opaco, de cor amarela esverdeada, de composição química bastante complexa e variável (PAYNE, 1989), contêm açúcares, colóides, proteínas, pentosanas, pectinas, gorduras, gomas, ceras, albuminas, silicato coloidal e materiais corantes como clorofila e antocianinas (OITICICA et al., 1975). No entanto segundo Paranhos (1987) e Silva (2003), a parte morfológica da cana-de-açúcar de interesse comercial é o colmo, que possui a sacarose industrializável.

Misturados ao caldo durante sua extração, entram no processo os pigmentos envolvidos na fabricação de açúcar (BOURZUTSCHKY, 2005). Valendo ressaltar que para Clarke e Legendre (1999), a coloração do caldo de cana-de-açúcar tem sua origem em vários compostos fenólicos e flavonoides dentre outros que podem refletir na cor final do produto.

Sendo assim, nas usinas, a qualidade do açúcar produzido está associada diretamente à eficiência do processo de clarificação do caldo, uma vez que a falta de um tratamento eficaz do caldo traduz-se em um açúcar de menor qualidade, com a presença de cor mais intensa, impurezas e pontos pretos (ENGENHO NOVO, 2008a). No Brasil o açúcar é clarificado utilizando-se o processo de sulfitação, o qual tem sido questionado por normas de segurança 
alimentar, pela qualidade do produto, perdas de sacarose durante 0 processamento, e também, por questões de ordem ambiental (HAMERSKI, 2009). $\mathrm{Na}$ sulfitação do caldo de cana-de-açúcar, $\mathrm{o} \mathrm{SO}_{2}$ é obtido pela queima do enxofre elementar, em fornos rotativos, na própria indústria. Este processo provoca sérios problemas ambientais, como chuvas ácidas, desconforto no ambiente de trabalho das fábricas e corrosão de metais nas instalações industriais. Além disso, a reação entre $\mathrm{OSO}_{2}$ gasoso e o caldo não é perfeita, devido à resistência do gás e do líquido à mistura, ocasionando variações no $\mathrm{pH}$ final do caldo sulfitado e, consequentemente, perdas de sacarose por inversão (RUAS, 1993).

Visto que o processo de tratamento do caldo de cana-de-açúcar por sulfitação, destinado à fabricação do açúcar branco, polui o meio ambiente devido à grande toxidade do enxofre e seus derivados (ARAÚJO, 2007), têm sido desenvolvidos diversos trabalhos investigativos, em busca de tecnologias alternativas e eficientes ao processo de clarificação atual, a sulfitação, produzindo um açúcar mais branco e isento de resíduos de enxofre (TRS; total reduced sulfides) e com eficiência para produção dos cristais de sacarose (AGUIAR, 2012). Dentre as opções, o uso de feixe de elétrons na decomposição de pigmentos vem se mostrando como uma técnica eficaz que pode resultar em clarificação dessas amostras irradiadas sem que estas alterem sua composição química. Este fato pode ser comparado aos estudos de Wotton et al. (1988) que verificaram a diminuição na coloração de grãos de arroz submetidos a radiação gama em doses de 10 KGy, sem que houvesse alterações na composição química sendo que esta mudança na coloração foi atribuída à oxidação de compostos fenólicos em melanoidinas.

Segundo Araújo (2007), os mercados, interno e externo tendem cada vez mais a consumir produtos alimentícios mais saudáveis, isentos de agrotóxicos, resíduos tóxicos de processos de fabricação e conservantes. Logo, o consumo do açúcar branco isento de resíduos de enxofre é uma realidade no mercado mundial. Dada a busca por tecnologias alternativas de clarificação do caldo de cana-de-açúcar na indústria brasileira, este Projeto de Pesquisa avaliou o perfil do caldo de cana-de-açúcar clarificado por meio de processos de oxidação por elétrons acelerados. E para fins de comparação os resultados obtidos foram comparados a resultados preliminares obtidos com amostras de caldo de canade-açúcar irradiados em fonte de cobalto-60 nas mesmas doses. 


\section{OBJETIVOS}

Dada à grande toxicidade do enxofre e seus derivados e a busca por tecnologias alternativas de clarificação do caldo de cana-de-açúcar na indústria brasileira, este Projeto de Pesquisa teve como objetivo avaliar os parâmetros de clarificação do caldo e/ou xarope por meio de processos de oxidação com elétrons acelerados nas doses 5, 10 e 20 kGy e, respectivo efeito na decomposição de pigmentos presentes no caldo, de acordo com os itens detalhados a seguir:

- Avaliação preliminar do processo de clarificação do caldo de canade-açúcar utilizando elétrons acelerados;

- Verificar a capacidade de redução de cor ICUMSA nos caldos e/ou xaropes por processo oxidativo com elétrons acelerados;

- Analisar o perfil composicional de açúcares antes e após aplicação do processo avançado de oxidação com elétrons acelerados sobre caldos e/ou xaropes;

- Analisar o perfil composicional de compostos fenólicos e flavonoides das amostras antes e após aplicação do processo avançado de oxidação com elétrons acelerados sobre caldos e/ou xaropes.

A título de comparação os resultados obtidos para o tratamento com radiação a partir de acelerador de elétrons foram comparados, nas mesmas doses, a resultados obtidos com caldo de cana-de-açúcar tratado com radiação gama, sendo alguns dos parâmetros avaliados para esta técnica. 


\section{REVISÃO DE LITERATURA}

\section{1 Cana-de-açúcar e posição no mercado}

A cana-de-açúcar é uma das gramíneas mais cultivadas nas regiões tropicais e subtropicais devido à grande contribuição socioeconômica que sua exploração representa, em razão de seu grande teor de sacarose (STUPIELLO, 1987). É capaz de produzir uma infinidade de produtos como: açúcar, álcool potável e/ou combustível, cachaça, servir para alimentação animal (variedades forrageiras), produção de garapa ou caldo de cana-de-açúcar após a moagem em moedores elétricos ou manuais (BRAZ, 2003).

Teve como centro de origem a região leste da Indonésia e Nova Guiné e ao longo de muitos séculos, se disseminou para várias ilhas do sul do Oceano Pacífico, aparecendo como planta produtora de açúcar na Índia tropical. Os Persas foram os primeiros a desenvolver técnicas de produção do açúcar estabelecendo as rotas do açúcar entre os países asiáticos e africanos (DELGADO e CESAR, 1977).

No Brasil, a cultura da cana-de-açúcar começou a ser realmente explorada em meados do século XV por Martins Afonso de Souza na capitania de São Vicente, mas foi a partir do século XVI que a cultura proporcionou grandes ganhos econômicos e sociais ao país, principalmente na produção de açúcar (JOSINO et al., 2005).

Segundo a USDA (Departamento de agricultura dos EUA) os principais países produtores de açúcar são Brasil, Estados Unidos, Índia, Tailândia e China. A produção do Brasil equivale a $19 \%$ de toda produção mundial, ou seja, 30,8 milhões de toneladas; a produção da Índia, segunda maior do mundo (16\%), é de 25,1 milhões de toneladas. Em terceiro lugar, a produção de açúcar dos Estados Unidos, representando $10 \%$ de toda produção mundial, é de 16,1 milhões de toneladas. 
No Brasil a produção de cana-de-açúcar dividida por região, revela que o norte-nordeste representa $15 \%$ e o centro-sul representa $85 \%$ da produção total do país segundo o IBGE (2012). A indústria sucroalcooleira é importante não somente para o agronegócio brasileiro como também pela relevância do açúcar para o consumo humano (RODRIGUES e MORAES, 2007). Para Fernandes et al. (2004), o açúcar proveniente da cana-de-açúcar está entre os produtos mais consumidos pela população e a indústria açucareira cresce continuamente, não só em porte, mas também em qualidade.

Para a atual safra 2012/13 a previsão total de cana-de-açúcar moída é de 602,2 milhões de toneladas, com aumento de 5,4\% em relação à safra $2011 / 12$, que foi de 571,4 milhões de toneladas, significando que a quantidade que será moída deve ser 30,7 milhões de toneladas a mais que a moagem da safra anterior. Sendo que para produção de açúcar serão esmagados aproximadamente 299,9 milhões de toneladas, correspondendo a 49,8\% do total, produzindo 38,85 milhões de toneladas, que equivalem a 777,0 milhões de sacas de $50 \mathrm{~kg}$ segundo levantamento da CONAB (2012).

No entanto para que o Brasil assuma uma posição de importante fornecedor mundial de alimentos e bioenergia, é preciso desenvolver "expertise" na construção de sistemas agroindústrias que serão cada vez mais transnacionais e deverão ser sustentáveis (NEVES e CONEJERO, 2007). Desde seu surgimento, a indústria de açúcar brasileira foi passível de grande regulação do Estado, principalmente pelo importante papel desempenhado pelo setor na economia nacional (RODRIGUES e MORAES, 2007).

Embora esses cenários sejam desenhados com o uso da tecnologia atual, é importante que aperfeiçoamentos científicos continuem ocorrendo. Nos últimos 30 anos, os avanços foram intensos e alguns resultados já podem ser observados, como a diminuição da perda no processo de fabricação, havendo uma melhoria na qualidade do açúcar, por exemplo, desde estudos que resultaram em uma maior variedade da cana-de-açúcar, passando por controles biológicos na sua produção, até chegar ao aumento na geração energética (autossuficiência) (CANA-DE-AÇÚCAR, 2012), porém, o processo de clarificação baseado na sulfitação não sofre quaisquer alterações ou melhorias (ARAÚJO, 2007). 


\subsection{Cultura da cana-de-açúcar}

A cana-de-açúcar (Saccharum spp.) possui diferentes origens, sendo algumas espécies da Oceania e outras asiáticas, e pelo seu enorme valor econômico e sua notável difusão geográfica, esta planta constitui no suporte da maior indústria agrícola do mundo (VILA, 2006). É uma planta perene da família Poaceae e gênero Saccharum; sendo sua propagação feita por meio dos colmos com 2-3 gemas. O colmo é cilíndrico, ereto, fibroso e rico em sacarose, dependendo da variedade (Figura 1).
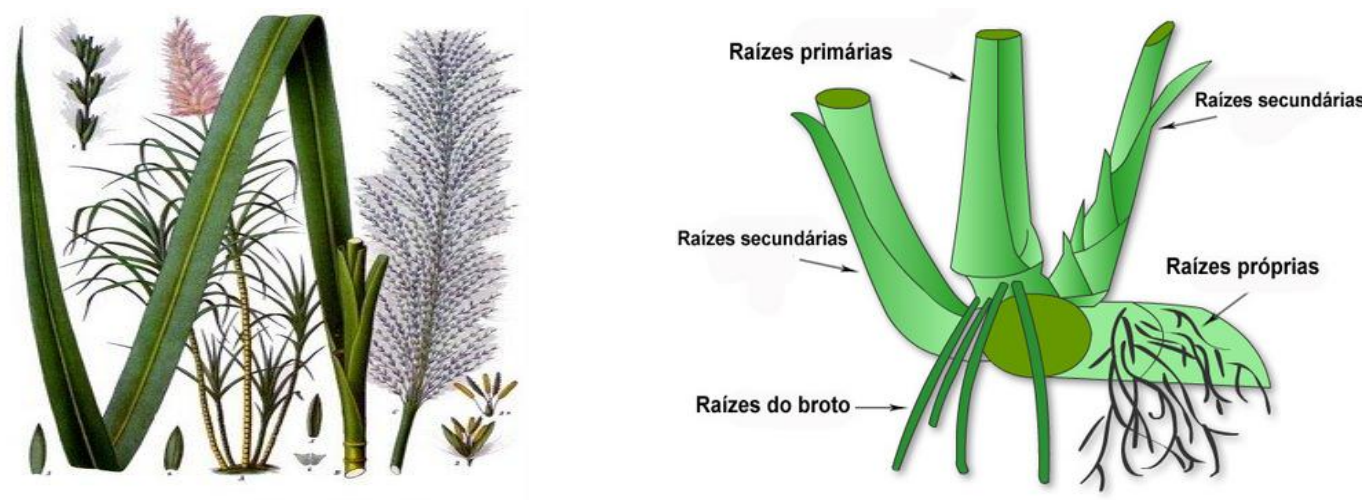

Figura 1 - Aspectos físico e fenológico de cana-de-açúcar (Saccharum spp.) (GODOY e TOLEDO, 1972).

De acordo com Andrade (2001) existem cerca de trinta espécies conhecidas e catalogadas sendo que das espécies reconhecidas pelos botânicos a mais plantada no Brasil é a $S$. officinarum, por apresentar baixo conteúdo de fibras e alto teor de sacarose (CHEN, 1993). O nome atual da espécie está relacionado ao fato de que todas as variedades de cana-de-açúcar atualmente cultivadas no mundo são para produção de açúcar, álcool, aguardente ou forragem. Essas variedades são híbridas e resultantes de cruzamentos entre diferentes espécies de plantas (ANDRADE, 2001).

A cana-de-açúcar compõe-se essencialmente por três partes, as raízes por onde absorve toda riqueza orgânica e mineral do solo; as folhas que realizam processos como respiração, transpiração e fotossíntese; pelo colmo que é a haste principal da planta, e tecnologicamente representa a parte de maior interesse, por 
ser a parte onde se acumula todo o açúcar produzido pelas folhas, contendo aproximadamente $90 \%$ de caldo (CASTRO e ANDRADE, 2007).

A cana-de-açúcar é uma planta que exige condições climáticas bem definidas para o seu cultivo. A cultura desenvolve-se bem onde o clima é caracterizado por uma estação chuvosa de intensa radiação solar seguida de período seco com menor intensidade luminosa. A temperatura ideal para a germinação é de $32^{\circ} \mathrm{C}$ e para o crescimento a temperatura ideal situa-se entre 20 $28^{\circ} \mathrm{C}$. Na fase de maturação a temperatura ótima varia de $12-20^{\circ} \mathrm{C}$, e influencia nos teores de sacarose da cana-de-açúcar (CASAGRANDE, 1991).

\subsection{Caldo de cana-de-açúcar e sua composição}

O caldo de cana-de-açúcar é considerado um líquido viscoso, de aparência opaca e cor amarelo esverdeado, de composição química bastante complexa e variável (PAYNE, 1989).

É constituído basicamente por água (80\%) e sólidos totais dissolvidos (20\%). Dos sólidos totais destacam-se os açúcares: sacarose (17\%), glicose $(0,4 \%)$, e frutose $(0,2 \%)$; os não açúcares orgânicos, constituídos por substâncias nitrogenadas, gorduras, ceras, pectinas, ácidos orgânicos e matérias corantes; e os não açúcares inorgânicos, representados pelas cinzas (STUPIELLO, 1987).

\subsubsection{Açúcares}

A sacarose (Figura 2) é um dissacarídeo conhecido desde o ano 200 a.C. (ROSSITER, 1992), podendo ser considerado como um dos carboidratos cristalinos mais abundante na natureza (KHAN, 1984). É produzido em larga escala por diversos países principalmente o Brasil. Em meio ácido a sacarose sofre hidrolise produzindo uma mistura equimolar de D-glicose (aldose) e Dfrutose (cetose), conhecida como açúcar invertido (SNYDER, 1995).

Este carboidrato (sacarose) é o componente de maior interesse no processamento da cana-de-açúcar, a qual se deseja obter na forma cristalizada, é susceptível a reações importantes. Dentre as quais, podem ser citadas, as reações de decomposição em meio ácido e básico, por efeito da temperatura, enzimas e microorganismos (MANTELATTO, 2005). 


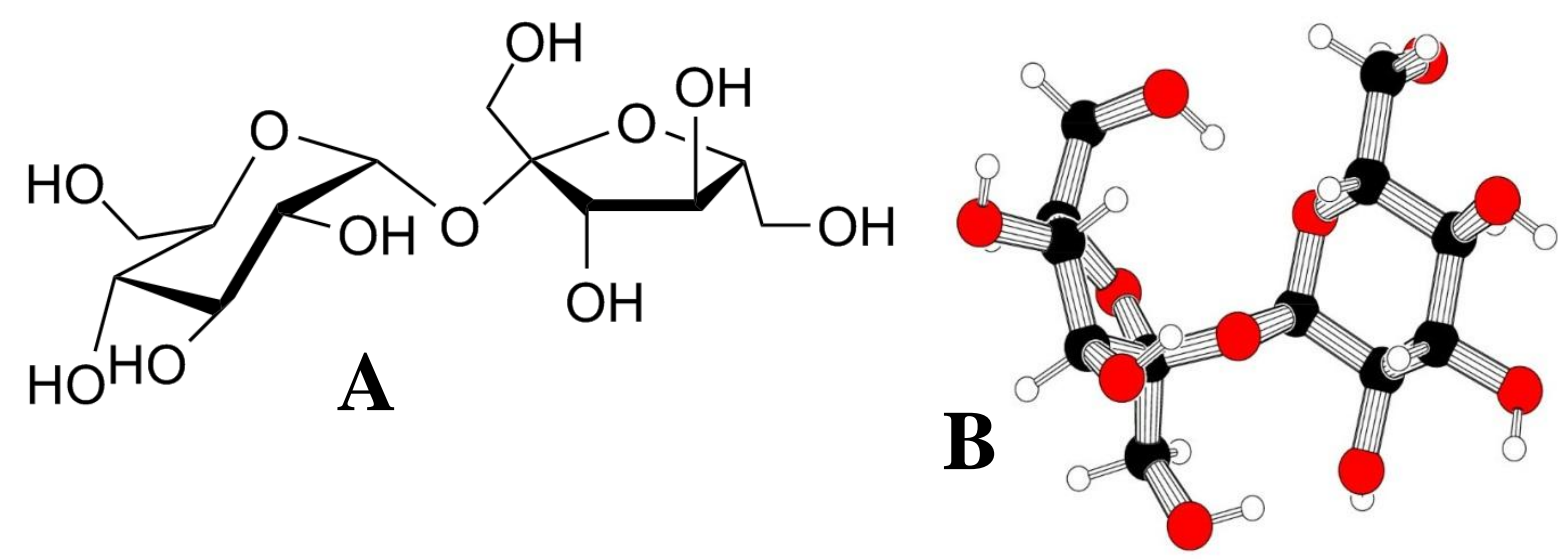

Figura 2 - Estrutura molecular da sacarose (SEaD/UFSCar, 2012). A: Fórmula molecular estrutural. B: Fórmula espacial tridimensional.

Já a glicose e a frutose são os principais monossacarídeos encontrados no caldo de cana-de-açúcar. A fórmula molecular de ambos é $\mathrm{C}_{6} \mathrm{H}_{12} \mathrm{O}_{6}$, entretanto difere em sua conformação estrutural, enquanto a glicose possui um anel contendo 6 átomos de carbono, piranose, a frutose possui anel contendo apenas 5 átomos de carbono, furanose (OETTERER et al., 2006).

Os açúcares redutores (Figura 3) são monossacarídeos que possuem a capacidade de reduzir o óxido de cobre. A principal influência dos açúcares redutores no processamento do caldo de cana-de-açúcar é devido aos efeitos dos produtos de sua decomposição que podem formar compostos altamente coloridos e complexos, de condensação coloidal além de substâncias melacigênicas como o ácido aspártico, podendo ainda interferir negativamente na morfologia final dos cristais de sacarose (HONIG, 1953; DELGADO e CESAR, 1977).
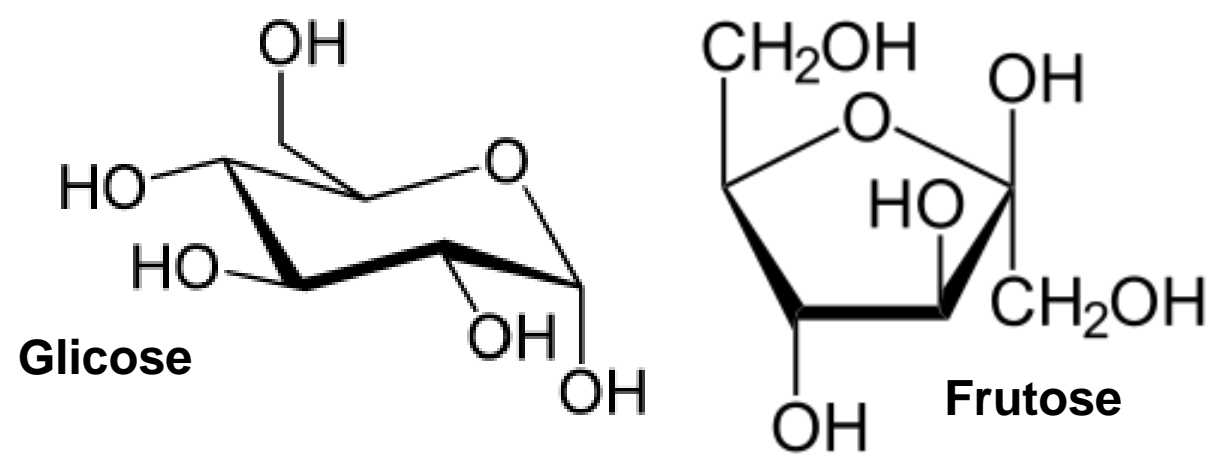

Figura 3 - Estrutura química das moléculas de frutose e glicose que representam os açúcares redutores do caldo de cana-de-açúcar (SEaD/UFSCar, 2012). 


\subsubsection{Não açúcares}

Todos os componentes presentes no caldo de cana-de-açúcar, excluindo os açúcares (sacarose, glicose e frutose), são considerados não açúcares, os quais se apresentam como elementos indesejáveis durante a produção de açúcar e principalmente quando este açúcar é destinado ao refino (SPENCER e MEADE, 1967).

A cor do caldo de cana-de-açúcar tem sua origem em vários compostos, como: fenólicos, antocianinas, flavonoides, melanoidinas, melaninas além de produtos de degradação alcalina da frutose (FERNANDES et al., 1999). No caldo, o desenvolvimento da cor se deve a presença de compostos orgânicos e inorgânicos que fazem parte da composição da cana-de-açúcar e estão presentes em seus colmos e cascas. A cor pode estar ainda relacionada com a maturação, variedade e tipo de solo (GODSHALI e LEGENDRE, 1988).

Para CLARKE e LEGENDRE (1999) a cor do caldo de cana-de-açúcar e consequentemente do açúcar tem sua origem em vários compostos, como: flavonoides, compostos fenólicos e pigmento sendo que aqueles que reagem com os açúcares redutores, são os que mais afetam a cor do caldo. Desta forma o conhecimento desses compostos é imprescindível na qualidade do açúcar.

Os compostos fenólicos (Figura 4) são originados do metabolismo secundário das plantas, derivados dos aminoácidos aromáticos fenilalanina e também da tirosina. Quimicamente, os compostos fenólicos podem ser definidos como substâncias que possuem um anel aromático contendo um ou mais grupos hidroxilas, incluindo seus derivados. Existe uma grande variedade de compostos fenólicos, incluindo os fenóis simples, derivados do ácido benzoico, ligininas e flavonoides, entre outros (SHAHIDI e NACZK, 2004).

Estudos realizados pela Fermentec (2005) em 30 amostras de açúcar de 11 usinas revelaram que quanto maior a concentração de fenólicos, maior a cor ICUMSA do caldo de cana-de-açúcar. Ainda de acordo com a Fermentec (2005), os teores de compostos fenólicos aumentam com a idade da planta, principalmente na interação de 13 a 15 meses e entre cultivares (RIPOLLI e RIPOLLI, 2004). Godshall e Legendre (1988) também observaram que os compostos fenólicos aumentam conforme a maturação da cana-de-açúcar, havendo diferenças entre cultivares. 
De acordo com Stupiello (2002) e Simioni et al. (2006) tem sido observado nas usinas que a matéria-prima que mostra maiores teores de compostos fenólicos acaba levando mais compostos percussores de cor no processo de fabricação do açúcar;

Os compostos flavonoides são uma classe muito extensa de produtos naturais distribuída no reino vegetal. Estão presentes em todas as partes das plantas, desde as raízes até as flores e frutos, sendo encontrados nos vacúolos das células. Ocorrem de forma livre (aglicona) ou ligada a açúcares (glicosídeos). Muitos são coloridos (amarelos), atuando na atração de insetos para a polinização da planta. Essa ampla classe de substâncias de origem natural, cuja síntese não ocorre na espécie humana, possui importantes propriedades farmacológicas que atuam sobre os sistemas biológicos, tais como ação antioxidante, antiinflamatória, antialérgica, antiviral e anticarcinogênica (YAO et al., 2004 e MARKHAN, 1982)

O grupo dos flavonoides é o mais crítico para o processamento do açúcar, e o responsável por até 30\% da cor do açúcar bruto em valores de $\mathrm{pH}$ igual a 7,0. Uma vez que esses compostos podem alterar sua coloração de acordo com o pH do meio. Vale destacar, como exemplo, as antocianinas, que apresentam coloração vermelha em meio ácido ou azul em meio alcalino (BOURZUTSCHKY, 2005).

Os flavonoides são derivados das flavonas e ocorrem nas plantas em uma variedade de formas estruturais, todas contendo 15 átomos de carbono em seu núcleo básicos arranjados na configuração $C_{6}-C_{3}-C_{6}$, isto é, são dois anéis aromáticos, ligados por três carbonos que podem ou não formar um terceiro anel, ligados a vários substituintes (VILA, 2006).

Os flavonoides glicosilados, como as antocianinas (Figura 4) são um grupo a ser estudado, sendo solúveis em água passando através do processo e podendo ser encontrados no açúcar. Estas se decompõem a altas temperaturas e pH formando compostos precursores de cor (GILLETT, 1953). 

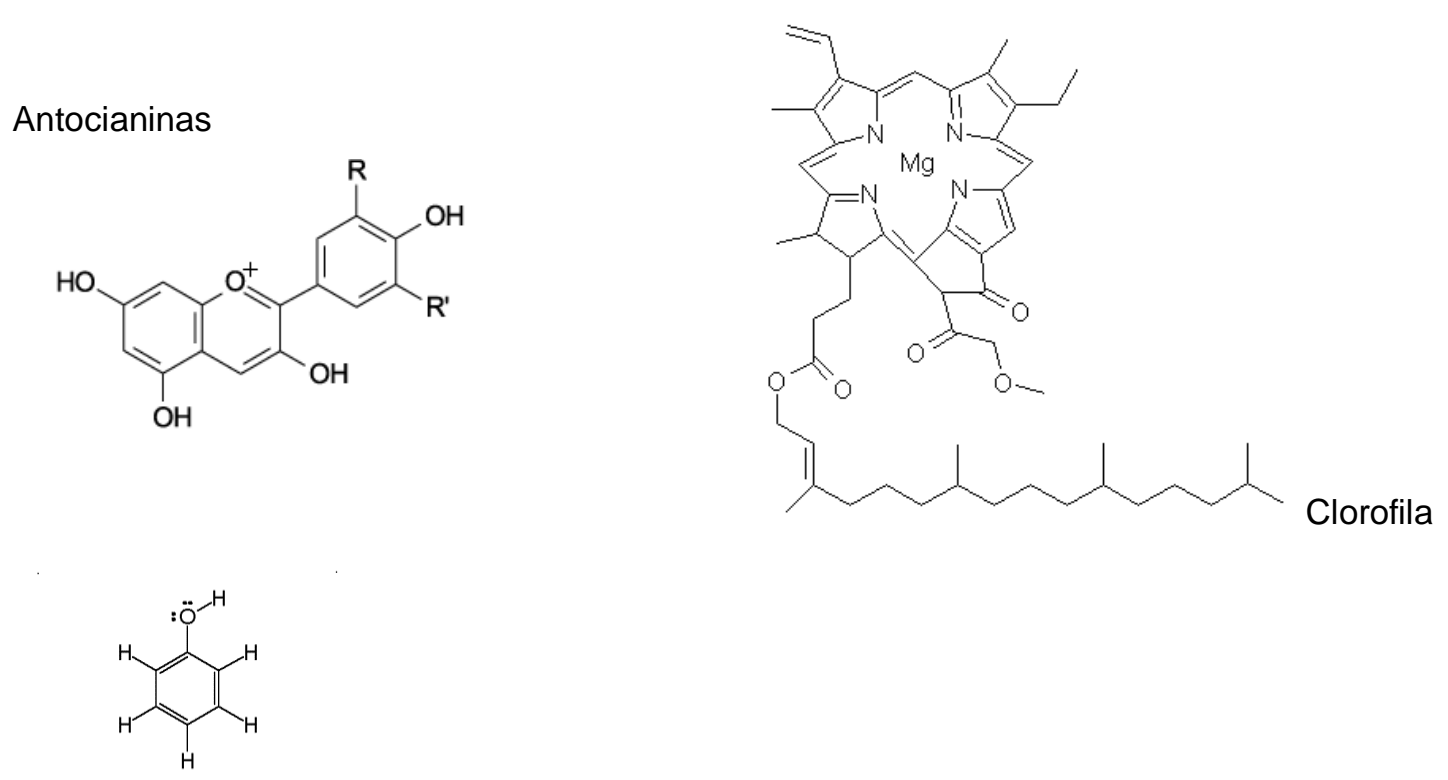

Estrutura básica do fenol

Figura 4 - Estruturas químicas de alguns pigmentos encontrados em cana-deaçúcar.

\subsection{Processos de formação de compostos coloridos em caldo de cana-de- açúcar.}

A formação de compostos coloridos no processo de produção de açúcar acontece principalmente pela degradação do açúcar (sacarose), e pela formação dos monossacarídeos glicose e frutose (MÓNICA, 2004).

Na natureza, os mono e dissacarídeos aparecem sob a forma estável de anel, porém são potencialmente ativos. Se a ligação hemiacetálica for rompida, por efeito de um álcali, a molécula fica aberta e com um grupamento redutor reativo. Tanto a glicose como a frutose, em meio alcalino, possuem o anel rompido e reagem participando, por exemplo, de reações de escurecimento não enzimáticas, onde se combinam com aminoácidos, gerando produtos coloridos (Reação de Maillard). Na produção de açúcar clarificado a presença destes açúcares redutores no caldo é indesejada, pois estes são transformados em ácidos orgânicos escuros e coloridos em temperaturas próximas a $100^{\circ} \mathrm{C} \mathrm{e} \mathrm{pH}$ igual a 8 (SOUZA, 1988; OETTERER et al., 2006; CASTRO e ANDRADE, 2007).

Esta reação foi reportada pela primeira vez pelo francês Louis Camille Maillard, em 1912, que observou a formação de pigmentos marrons (melanoidinas) durante o aquecimento de uma solução de glicose e glicina. As reações de escurecimento não enzimático envolvem fatores como $\mathrm{opH}$, 
temperatura, umidade e presença de açúcares (ESKIN et al., 1971). As reações não somente formam melanoidinas como também vários compostos voláteis e de aroma (aldeídos, cetonas e pirazina) via intermediários tais como HMF (hidróximetil-furfural), redutonas, aldiminas e outros (HODGE, 1953).

Naturalmente, as melanoidinas estão distribuídas em alimentos (PAINTER, 1998), bebidas e amplamente encontradas em produtos da indústria sucroalcooleira (melaço e açúcar). Estas constituem um grande problema, principalmente durante a cristalização devido à perda de pureza do açúcar cristal branco (MERSAD et al., 2003). No entanto, tem sido sugerido que as melanoidinas podem ser descoloridas pela ação de algumas espécies de oxigênio ativo $\left(\mathrm{O}_{2}^{-}, \mathrm{H}_{2} \mathrm{O}_{2}\right)$ produzidas por reações catalisadas por enzimas oxidativas (CHANDRA et al., 2008).

Durante a produção de açúcar, pode haver ainda a formação de caramelos provenientes de reações de degradação e condensação da glicose e frutose em altas temperaturas (ARAÚJO, 2007). Uma vez que o aquecimento da sacarose, a temperaturas elevadas $\left(>140^{\circ} \mathrm{C}\right)$, desencadeia um grupo complexo de reações químicas originando produtos fortemente coloridos. A termólise causa a desidratação das moléculas de açúcar com a introdução de dupla ligação e formação de anéis anidros. Ligações duplas conjugadas absorvem luz e produzem cor. Os anéis insaturados condensam-se formando polímeros de coloração escura, denominados caramelos (FENNEMA, 1996).

Caramelos são produtos formados a partir da degradação térmica da sacarose, com elevado peso molecular que aumentam com o tempo e a temperatura, pela polimerização crescente. Eles têm somente uma carga leve e não são sensíveis ao pH (DAVIS, 2001).

Eles são compostos coloidais com uma tendência para permanecer preferencialmente na superfície do cristal, afetando à qualidade do açúcar branco. Caramelos são formados por aquecimento de xaropes concentrados de sacarose em temperaturas acima de $210^{\circ} \mathrm{C}$. A geração de cor em caramelização requer que os açúcares, normalmente monossacarídeos, devam primeiramente sofrer rearranjos intramoleculares $(\mathrm{KROH}, 1994)$. Dependendo do tempo e da temperatura, são obtidas soluções de cor amarelada ou castanhas (MÓNICA, 2004). 


\subsection{Tratamento do caldo de cana-de-açúcar}

O processo de fabricação de açúcar visa a extração do caldo contido na cana-de-açúcar, seu preparo e concentração, culminando nos vários tipos de açúcares conhecidos, como: demerara, mascavo, cristal, refinado, líquido e VHP. Como já destacado anteriormente, a clarificação de alguns tipos de açúcares visa à obtenção de um caldo livre de impurezas, envolvendo etapas de peneiragem, tratamento químico, aquecimento, decantação e filtração do caldo (BEM et al., 2006). Nas usinas, a qualidade do açúcar está associada diretamente à eficiência do processo de clarificação do caldo, sendo que a falta de um tratamento eficaz do caldo traduz-se em um açúcar de menor qualidade, com a presença de cor mais intensa, impurezas e pontos pretos (ENGENHO NOVO, 2008a). Quanto mais baixa a unidade ICUMSA (U.I.), mais claro ou mais branco é o açúcar gerado. À medida que o índice da cor ICUMSA aumenta, o açúcar vai adquirindo uma coloração mais escura (SIMIONI, et al., 2006; LEITE, 2000; ICUMSA, 1994; CLARKE et al., 1985).

\subsubsection{Colheita, preparo, extração e peneiragem do caldo de cana-de-açúcar}

A cana-de-açúcar pode ser colhida verde, sem queimar ou ainda queimada, manualmente ou mecanicamente, inteira ou picada. Passa pelo processo de pesagem e é conduzida para lavagem, para retirada da terra proveniente da lavoura. (COPERSUCAR, 2010). Posteriormente a cana-deaçúcar passa por um preparo onde ela é desintegrada para facilitar a extração do caldo contido nas células. Este preparo é importante par incrementar a capacidade das moendas. Atualmente, na indústria sucroalcooleira, os equipamentos mais utilizados neste preparo são as facas rotativas, seguidas dos desfibradores. (CAMARGO, 1990). O caldo misto pode ser extraído da cana-deaçúcar por dois diferentes mecanismos:

- Moagem: as moendas convencionais são constituídas de três rolos (ternos), dispostos em triângulo, de modo que a fibra seja comprimida duas vezes: entre o rolo superior (móvel) e o de entrada (fixo), e entre o rolo superior e o de saída (fixo) como na Figura 5. No entanto, somente a pressão não expele mais do que $90 \%$ do caldo contido nas fibras, e torna-se necessário fazer a embebição do bagaço para 
recuperar maior volume de caldo. (MARQUES et al., 2001 e MARQUES et al., 2006).

- Difusão: a difusão é um fenômeno osmótico pelo qual uma solução migra para outra de concentração diferente, através de uma membrana permeável à solução. A sacarose é extraída em contracorrente com o caldo diluído e a água; a cana-de-açúcar desfibrada entra em uma extremidade do aparelho e na outra sai esgotada, sendo conduzida para moendas em prensas especiais para secar o bagaço, que será enviado às caldeiras com 50\% de umidade (SOUSA, 1995). De acordo com BIAGI (2005), o processo de extração por difusão é mais eficiente quando comparado aos processos de moagem tradicionais.

O caldo de cana-de-açúcar extraído (caldo misto) contém impurezas grosseiras, tais como: bagaço, pedaços de cana-de-açúcar, areia e terra, que são removidos por peneiras. A remoção destas impurezas faz-se necessária antes que se passe a fase de clarificação, pois as mesmas promovem frequentes entupimentos de bombas, propiciando incrustações em tubulações dos corpos aquecedores e evaporadores. Vários são os tipos de peneiras utilizadas na prática da remoção de impurezas grosseiras presentes no caldo e podem ser reunidas em três tipos básicos: fixas (Cush-Cush e DSM), vibratórias e rotativas. As utilizadas com maior frequência e as primeiras a remover as impurezas do caldo misto, são as do tipo Cush-Cush. O caldo peneirado é coletado na parte inferior em um tanque de recepção (DELGADO e CESAR, 1977).

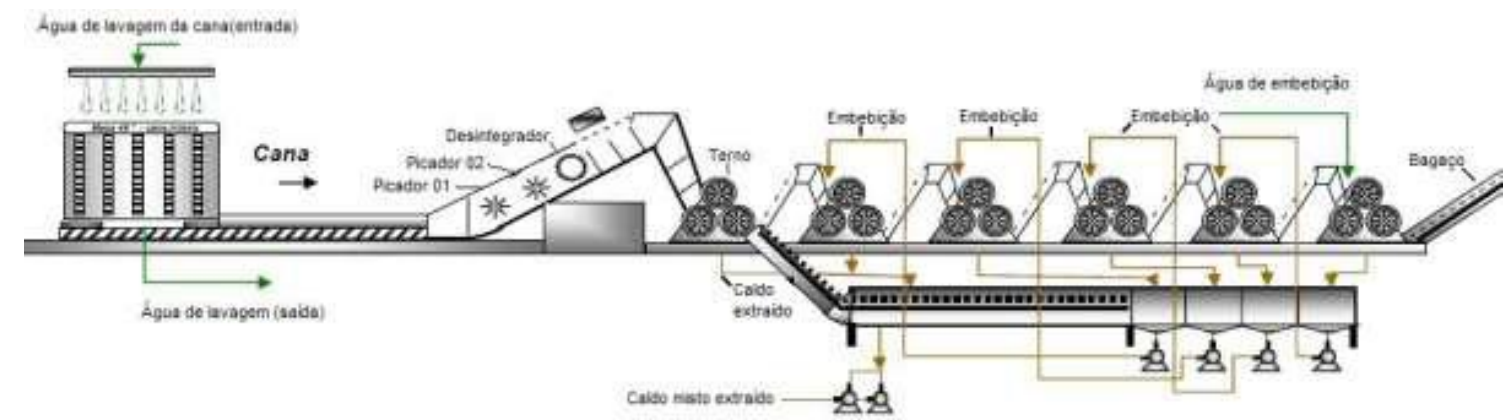

Figura 5 - Extração do caldo de cana-de-açúcar em moendas (CAMARADO, 2008). 


\subsubsection{Clarificação do caldo de cana-de-açúcar}

O objetivo principal da clarificação é eliminar a quantidade máxima de impurezas presentes no caldo de cana-de-açúcar, visando obter um caldo claro, límpido e brilhante mediante a coagulação máxima de colóides e a formação de precipitados que adsorvam e arrastem as impurezas coloidais (SOUZA, 1988).

A clarificação do caldo de cana-de-açúcar ocorre através da coagulação, floculação e precipitação dos coloides e substâncias corantes, eliminadas por decantação e filtração, ou seja, forma-se um precipitado insolúvel que absorve e arrasta as impurezas do caldo. A floculação pode ser obtida por uma mudança de $\mathrm{pH}$ do meio, utilizando-se reagentes químicos e pelo aquecimento (LEITÃO, 1973). A clarificação do caldo envolve basicamente as etapas de sulfitação (contato contracorrente do caldo e $\mathrm{SO}_{2}$ ), calagem (o caldo recebe leite de cal) e/ou adição de compostos poliméricos de cadeia longa, sendo o caldo aquecido e ocorrendo decantação e, consequente, formação do caldo clarificado que segue para a etapa de concentração (TFOUNI et al., 2007). No Brasil predominam dois modelos de clarificação: defecação simples (emprega apenas cal e aquecimento para obtenção de açúcar bruto), e sulfo-defecação (antes do tratamento com cal e aquecimento, ocorre adição de $\mathrm{SO}_{2}$ ao caldo para fabricação de açúcar cristal branco) (KOBLITZ, 1998).

\subsubsection{Defecação simples}

A calagem ou defecação simples consiste na adição de cal hidratada (leite de cal), suficiente para neutralizar os ácidos orgânicos presentes no caldo. Em geral, são utilizadas 500 a $800 \mathrm{~g}$ de cal por tonelada de cana-de-açúcar, de modo a obter $\circ \mathrm{pH}$ do caldo entre 7,0 e 7,5. Na sequencia, o caldo caleado é aquecido a $90-105^{\circ} \mathrm{C}$ (HONIG, 1953). A presença de cal $\left(\mathrm{Ca}(\mathrm{OH})_{2}\right)$ e o aumento da temperatura levam a formação de um precipitado flocoso de composição complexa, na qual se encontram partículas de fosfato de cálcio, sais de ácidos orgânicos, proteínas desnaturadas (albumina), gorduras, ceras e gomas. Esse precipitado adsorve e arrasta grande parte do material suspenso no caldo, sendo posteriormente separado por decantação (HUGOT, 1977). 


\subsubsection{Sulfo-defecação}

O emprego de anidro sulfuroso no tratamento do caldo misto restringese à produção de açúcar branco. A indústria de açúcar utiliza-se da combustão de enxofre para obtenção do gás sulfuroso. Esta operação é realizada em fornalhas e a combustão do enxofre se realiza a $250^{\circ} \mathrm{C}$, produzindo o dióxido de enxofre. Esse gás é então resfriado, para reduzir ao máximo a possibilidade de formação de $\mathrm{SO}_{3}$ que representa um consumo inútil de enxofre no que concerne ao tratamento do caldo (CAMARGO, 1990).

O sulfito é adicionado ao caldo misto até se obter um pH 4,0 e 4,5 (de 150 a $300 \mathrm{~g}$ de enxofre por tonelada de cana-de-açúcar), sendo o caldo misto préaquecido a $40^{\circ} \mathrm{C}$ e, em seguida, enviado à calagem. A neutralização do caldo sulfitado conduz a formação de sulfito de cálcio que age adsorvendo compostos coloridos, bem como outras impurezas. O sulfito também atua na descoloração temporária de alguns elementos, provavelmente devido à combinação do $\mathrm{SO}_{2}$ com os açúcares redutores presentes, bloqueando o grupo funcional carbonila, impedindo a formação de oligossacarídeos coloridos (caramelos) (HONIG, 1953).

Durante o processo de sulfitação quando o gás é borbulhado no caldo, há reação com a água e esta solução contém $\mathrm{H}_{2} \mathrm{SO}_{3}$ molecular não dissolvido e íons dissolvidos de $\mathrm{HSO}_{3}^{-}$(DELGADO e CESAR, 1990), conforme detalhado abaixo:

$$
2 \mathrm{SO}_{3}+2 \mathrm{H}_{2} \mathrm{O} \longleftrightarrow 2 \mathrm{H}_{2} \mathrm{SO}_{3} \longleftrightarrow 2 \mathrm{H}^{+}+2 \mathrm{HSO}_{3}^{-}
$$

A ação do dióxido de enxofre, $\mathrm{SO}_{2}$, ao caldo apresenta duas principais funções: a primeira é a eliminação de materiais corantes, propriedade comum a todos os ácidos, e a segunda é a possível transformação dos sais férricos, resultantes do contato direto com equipamentos como tanques, tubulações e moendas, em compostos ferrosos incolores (HUGOT, 1977). 


\subsection{Restrições ao uso de enxofre em alimentos}

Apesar do processo de sulfitação ser o método mais utilizado no tratamento do caldo de cana-de-açúcar, no Brasil e em países produtores de açúcar branco como pode ser observado na Figura 6, este processo apresenta alguns aspectos que têm restringido o seu uso. Entre estes, destacam-se as normas de segurança alimentar, questões de ordem operacional, tecnológica e ambiental (HAMERSKI, 2009).

Os agentes sulfitantes são classificados como aditivos alimentares e atuam na inibição da deterioração provocada por bactérias, fungos e leveduras em alimentos ácidos, e na inibição de reações de escurecimento enzimático e não enzimático durante processamento e estocagem. Adicionalmente, os sulfitos são utilizados como agentes antioxidantes e redutores em várias aplicações tecnológicas (TAYLOR et al., 1986; LECLERCQ et al., 2000; RIBERA et al., 2001).

Do ponto de vista do processo, a sulfitação apresenta sérios problemas de irregularidade, dificuldade operacional, perdas de sacarose por se trabalhar em valores de $\mathrm{pH}$ que chegam na faixa de 3,8-4,3, e devido a reação de solubilização entre $\mathrm{o} \mathrm{SO}_{2}$ gasoso e o caldo não ser perfeita, ocasionando variações de $\mathrm{pH}$ final no caldo sulfitado e a consequente inversão da sacarose. Isto leva a obtenção de produtos de qualidade inferior, incluindo, mas não limitando, a alta concentração de $\mathrm{SO}_{2}$ e problemas de estocagem (CHOU et al., 2006).

Os sulfitos são utilizados desde a antiguidade os gregos usavam 0 anidrido sulfuroso para desinfeccionar suas casas; os romanos e egípcios os empregavam na sanitização de recipientes destinados ao acondicionamento dos vinhos. No entanto como preservativo de alimentos, sua utilização data do século XVII, tendo sido aprovado o seu uso nos EUA no início dos anos 1800. Dentre os alimentos que podem apresentar sulfitos destacam-se as bebidas alcoólicas como vinhos e cervejas; artigos de padaria como biscoitos, bolachas e tortas, bebidas que contenham açúcar ou xarope de milho, sucos de frutas congelados; laticínio como requeijão; peixes crustáceos e moluscos; frutas como uvas frescas, frutas secas; gelatinas; legumes enlatados; açúcares como mascavo, açúcar branco e cristal, entre outros (TELLES- FILHO, 2012) ${ }^{1 .}$

\footnotetext{
${ }^{1}$ http://www.asmabronquica.com.br/medical/tipos_de_asma_asma_sulfitos.html (1 of 9)
} 
Apesar da ampla utilização de sulfitos na indústria de alimentos, inúmeros efeitos adversos à saúde humana têm sido relacionados à ingestão desses aditivos alimentares, entre eles náusea, irritação gástrica local, urticária e broncoespasmos em indivíduos asmáticos sensíveis (MACHADO, 2006).

O Codex Alimentarius estabelece um limite de $15 \mathrm{mg} \cdot \mathrm{kg}^{-1}$ em açúcar branco para consumo direto e movimentos internacionais existem na direção de reduzir este teor a $10 \mathrm{mg} \cdot \mathrm{kg}^{-1}$. No passado, a presença de elevados teores de $\mathrm{SO}_{2}$ no açúcar era responsável pela oxidação interna das embalagens metálicas e tampas de frascos de vidro. Atualmente a principal preocupação ou tendência para a eliminação do enxofre no açúcar está associada a possíveis efeitos alergênicos, sentidos por uma pequena porcentagem de pessoas (OLIVEIRA, 2007).

De acordo com as normas de segurança alimentar, observa-se uma tendência mundial na redução do uso de compostos a base de enxofre nos alimentos devido aos seus possíveis efeitos nocivos ao consumidor Além disso, a sulfitação é conhecida por proporcionar sérios problemas de irregularidade do processo como dificuldade operacional, perdas de sacarose e originar produtos de qualidade inferior, incluindo, mas não limitando, a alta concentração de $\mathrm{SO}_{2}$ que levam problemas de estocagem, como odor característico e escurecimento ao longo do tempo (CHOU et al., 2006).

$\mathrm{Na}$ sulfitação do caldo de cana-de-açúcar, o $\mathrm{SO}_{2}$ é obtido pela queima do enxofre elementar, em fornos rotativos, na própria indústria. Este processo provoca sérios problemas ambientais, como chuvas ácidas, desconforto no ambiente de trabalho das fábricas e corrosão de metais nas instalações

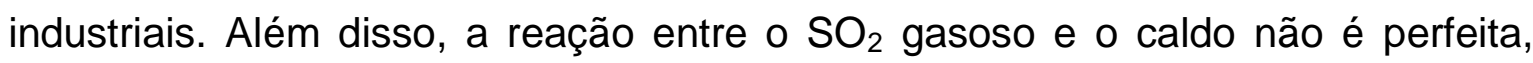
devido à resistência do gás e do líquido à mistura, ocasionando variações no $\mathrm{pH}$ final do caldo sulfitado e, consequentemente, perdas de sacarose por inversão (RUAS, 1993). 


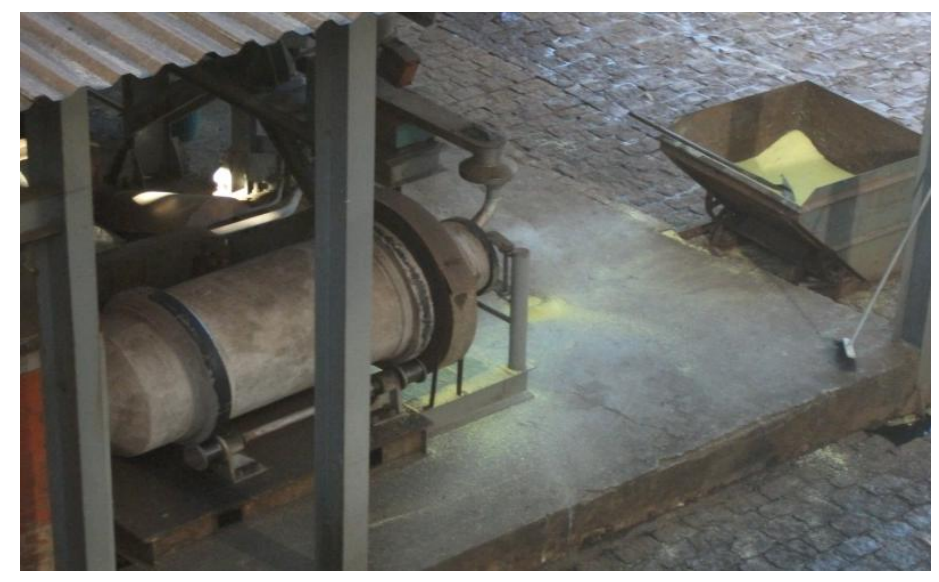

Figura 6 - Disposição de enxofre na usina açucareira utilizado nas enxofreiras para introdução no processo de clarificação do caldo de cana-de-açúcar (Fonte: Arquivo pessoal, 2012).

\subsection{Processos ionizantes na clarificação do caldo de cana-de-açúcar}

Dado que o processo de tratamento do caldo de cana-de-açúcar por sulfitação, destinado à fabricação do açúcar branco, polui o meio ambiente devido à grande toxidade do enxofre e seus derivados, outros métodos de clarificação do caldo e do xarope têm sido propostos, numa tentativa de reduzir a emissão de intermediários tóxicos e agregados ao produto final. Segundo Araújo (2007), o mercado interno e externo tende cada vez mais a consumir produtos alimentícios mais saudáveis, isentos de agrotóxicos, resíduos tóxicos de processos de fabricação e conservantes. Logo, o consumo do açúcar branco, isento de resíduos de enxofre, é uma realidade no mercado mundial.

Recentemente, a busca por novas tecnologias para a clarificação do caldo tem sido analisada por diversos setores da agroindústria da cana-deaçúcar. Entre estas opções tecnológicas, o uso de agentes oxidantes ou de enzimas oxidativas é uma das propostas de pesquisas científicas feitas no país e em outros (OKUNO e TAMAKI, 2002).

A utilização de elétrons acelerados se torna um método alternativo, propostos para esta finalidade. O feixe de elétrons é um tipo de radiação ionizante, a qual é produzida em aceleradores de elétrons. Estes podem ser definidos como sistemas onde se estabelece um potencial de alta voltagem entre um cátodo e um ânodo num tubo de vácuo. O cátodo emite feixe de elétrons chamados de raios catódicos ou feixes eletrônicos, que seguem o mesmo 
princípio do tubo de televisão, onde a grande diferença é que este último utiliza aproximadamente $25000 \mathrm{~V}$ de energia, enquanto a tensão utilizada no acelerador é da ordem de milhões de volts (RELA, 2003).

Em alimentos com alto conteúdo de água ( $\geq 60 \%$ ), a radiação ionizante é absorvida pelo composto em maior concentração, ou seja, a água, podendo provocar a formação dos radicais hidroxilas $(\mathrm{OH})$, elétrons solvatados $\left(e_{a q}\right)$, átomos de hidrogênio $(H)$, hidrogênio molecular $\left(H_{2}\right)$ e peróxido de hidrogênio $\left(\mathrm{H}_{2} \mathrm{O}_{2}\right)$ e estes radicais por sua vez interagem com os componentes dos alimentos, interação essa denominada secundária (PHILLIPS, 1961; SCHWARZ, 1981; MUÑ̃Z et al., 1985).

Os radicais livres podem combinar-se para formar algumas moléculas ativas, como é o caso do peróxido de hidrogênio $\left(\mathrm{H}_{2} \mathrm{O}_{2}\right)$, produtos estes importantes também do ponto de vista de desinfecção (RELA, 2003), bem como, na clarificação de produtos coloridos, visto que Chandra e Bharagava (2008) verificou ser possível a descoloração de melanoidinas por estas espécies reativas.

As alterações químicas sofridas pelos alimentos irradiados são induzidas pela ação direta de macro e micronutrientes ou uma ação indireta provocada por intermediários reativos formados pela radiólise da água $(\mathrm{OH}$ et al., 2004). As radiações ionizantes provenientes de raios $\gamma$ ou de feixes de elétrons são capazes de quebrar ligações químicas quando são absorvidas pelos compostos. Os produtos da ionização podem ser eletricamente carregados (íons) ou neutros (livres de radicais). Estes então podem promover reações que causam alterações nos compostos químicos irradiados, conhecidas como radiólise; as quais são reações que causam a destruição de microrganismos, insetos e parasitas durante a irradiação de alimentos (FELLOWS, 2006), bem como modificações na estrutura química dos compostos, como verificado por Aguiar et al. (2009).

As formações dos átomos de hidrogênio e das hidroxilas ocorrem quando a radiação eletromagnética ou partículas carregadas interagem com a água. A cada ponto em que ocorre a retirada de elétrons, os elétrons secundários formados possuem energia suficiente para futuras ionizações (retirada de elétrons). Segundo Phillips (1961), após $10^{-18}$ a $10^{-16} \mathrm{~s}$ da passagem da partícula pela água ocorre uma série de reações, conforme pode se resumir a seguir: 


$$
\begin{aligned}
\mathrm{H}_{2} \mathrm{O}+\mathrm{e}_{1} \longrightarrow \mathrm{H}_{2} \mathrm{O}^{\oplus}+\mathrm{e}_{2}+\mathrm{e}_{\mathrm{s}} \\
\mathrm{H}_{2} \mathrm{O}+\mathrm{e}_{\mathrm{s}} \longrightarrow \mathrm{H}_{2} \mathrm{O}^{\oplus}+\mathrm{e}_{\mathrm{s} 1}+\mathrm{e}_{\mathrm{s}} \\
\mathrm{H}_{2} \mathrm{O}^{\oplus}+\mathrm{H}_{2} \mathrm{O} \longrightarrow \mathrm{H}_{3} \mathrm{O}^{\oplus}+{ }^{\cdot} \mathrm{HO} \\
\mathrm{H}_{2} \mathrm{O} \longrightarrow \mathrm{H}+\mathrm{OH}^{-}
\end{aligned}
$$

Desta forma a radiólise da água pode ser resumida pelas reações parciais e sua reação total, descritas abaixo (PHILLIPS, 1961) :

$$
\begin{gathered}
\mathrm{H}_{2} \mathrm{O} \longrightarrow \mathrm{H}_{2} \mathrm{O}^{\oplus}+\mathrm{e}^{-} \\
\mathrm{H}_{2} \mathrm{O}^{+}+\mathrm{aq} . \longrightarrow \mathrm{H}^{\oplus} \mathrm{aq}+\mathrm{OH} \\
\mathrm{e}^{-}+\mathrm{H}_{2} \mathrm{O} \longrightarrow \mathrm{OH}^{-}+\mathrm{H} \\
\mathrm{OH}^{-}+\mathrm{H}^{+} \longrightarrow \mathrm{H}_{2} \mathrm{O} \\
\mathrm{H}_{2} \mathrm{O} \longrightarrow \mathrm{H}+\mathrm{OH}
\end{gathered}
$$

Onde: $e_{1}$ e $e_{2}$ são os elétrons de recuo e $e_{s}$ são os elétrons secundários.

As espécies formadas $\left({ }^{\circ} \mathrm{OH}, e_{a q}{ }^{-}\right.$e $\left.\mathrm{H}\right)$ são bastante reativas, portanto, duram pouco tempo em solução. O radical hidroxila é um agente oxidante, enquanto o elétron aquoso e o átomo de hidrogênio são agentes redutores. $A$ formação de hidrogênio e do $\mathrm{H}_{2} \mathrm{O}_{2}$ ocorre por combinação dos radicais citados anteriormente. Estas reações ocorrem em $10^{-7} \mathrm{~s}$ após a passagem das partículas carregadas, sendo as reações demonstradas por Phillips (1961), ou seja: 


$$
\begin{gathered}
\mathrm{H}+\mathrm{H} \longrightarrow \mathrm{H}_{2} \\
\mathrm{OH}+\mathrm{OH} \longrightarrow \mathrm{H}_{2} \mathrm{O}_{2}
\end{gathered}
$$

Os efeitos da radiação nos materiais em geral, com a radiação ionizante são devidos ao grande numero de interações da radiação com os átomos e moléculas. A principal interação é a ionizante que ocorre quando um átomo absorve a energia da interação da radiação para liberar seu elétron de ligação e tornar-se um íon carregado e essa energia de degradação pode continuar ionizando outros átomos durante a sua trajetória (SAMPA, 1993). No caso de uma interação que resulta na absorção de somente uma parte da energia de ionização, pode ocorrer um processo de excitação onde o átomo ionizado combina com o elétron livre para um estado excitado e esse átomo retorna ao seu estado fundamental através de vários processos de relaxação, como por exemplo, fluorescência onde o elétron libera energia ao retornar de uma camada mais externa para sua órbita mais interna (RELA, 2003).

Outro processo de relaxação é a quebra de moléculas com ligações covalentes onde os radicais livres possuem grandes energias de reatividade química. Os radicais livres têm importante papel no processo de tratamento por radiação, pois após a sua formação possuem uma vida muito curta mas muito ativa formando previamente equações como rearranjo, dissociação, adição e substituição pela interação com átomos e moléculas vizinhas até que a energia dos radicais livres seja dissipada em um processo de terminação como combinação, desproporcionamento ou transferência de elétrons (COOPER, 1995).

Logo, os elétrons injetados nos processos de irradiação interagem com a matéria e perdem energia em sucessivas interações, formando produtos radiolíticos. Sendo que a relação mais importante que governa a formação de produtos radiolíticos é a que apresenta eficiência da conversão da energia dos elétrons em processos químicos, que por sua vez é intimamente dependente da secção de choque (probabilidade de excitação e ionização) das soluções líquidas e de suas concentrações (RELA, 2003). 
$\mathrm{Na}$ interação da radiação com o produto a ser tratado ocorrem reações complexas em frações de segundos quando o material atravessa o campo de radiação produzido pelo feixe de elétrons. $O$ bombardeamento de produtos por radiação gama, por raios- $X$ ou por elétrons são técnicas efetivas no processamento por radiação ionizante, sendo a principal diferença entre essas técnicas o tipo da radiação primária que interage com o produto a ser tratado (RELA, 2003). Desta forma, o presente Projeto de Pesquisa buscará desenvolver técnicas para aplicação desta tecnologia na clarificação do caldo e/ou xarope de cana-de-açúcar, através da degradação de compostos coloridos pela ação da alta energia gerada ou ação de compostos oxidantes formados pela radiólise.

Após a primeira interação, o mecanismo de transporte de energia no interior do produto é o mesmo para os três tipos de radiação, prevalecendo os elétrons secundários (elétrons expulsos de suas orbitas) que produzem a maioria das excitações e ionizações provocando os efeitos químicos (CHANDRA, 1992). Desta forma, o presente Projeto de Pesquisa buscará desenvolver técnicas para aplicação desta tecnologia na clarificação do caldo e/ou xarope de cana-deaçúcar, através da degradação de compostos coloridos pela ação da alta energia gerada ou ação de compostos oxidantes formados pela radiólise. 


\section{MATERIAL E MÉTODOS}

\subsection{Material Vegetal}

A cana-de-açúcar cv. SP 81-3250 utilizada neste Projeto de Pesquisa foi proveniente de plantação, no município de Piracicaba/SP na Estação Experimental "Fazenda Areão" da Escola Superior de Agricultura Luiz de Queiroz

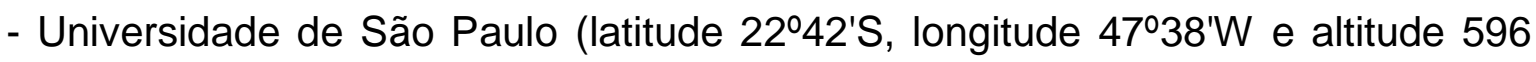
$\mathrm{m}$ ), onde o solo classifica-se como terra roxa estruturada (Alfisol), série Luiz de Queiróz, apresentando declividade média de 5\%, durante os períodos das safras de 2010/11 e 2009/2010. O caldo foi obtido em moenda Mausa (Piracicaba/SP) e peneirado em malha de 0,394" de diâmetro de poro.

\subsection{Ensaios de clarificação com irradiação em acelerador de elétrons}

Os ensaios para verificar a capacidade de clarificação dos elétrons acelerados foram conduzidos, em bateladas, onde $250 \mathrm{~mL}$ das amostras foram introduzidas em sistemas de irradiação (tipo "batch") vidro boro silicato (Pirex) e foram irradiadas à temperatura ambiente, em presença de ar, nas doses de 5, 10 e 20 kGy. Utilizou-se o acelerador de elétrons modelo Dynamitron-job188 fabricado pela Radiation Dynamics, localizado no Instituto de Pesquisas Energéticas e Nucleares (IPEN), em São Paulo.

As amostras foram espalhadas em refratários de vidro temperado formando uma espessura de $4,45 \mathrm{~mm}$, a superfície livre foi envolta em filme plástico de PVC. Para a dose de $5 \mathrm{kGy}$, a corrente do feixe foi fixada em 5,61 mA e energia de 1,499 MeV. A bandeja foi levada ao feixe com velocidade que resultasse em uma taxa de dose de 11,21 kGy/s, a amostra recebeu dose de 2,5 kGy a cada passagem. As demais doses (10 e $20 \mathrm{kGy}$ ) foram recebidas pela amostra no sistema de esteira, mas com corrente de feixe de 5,61 mA e energia de 1,499 MeV, proporcionando uma taxa de dose de 22,38 kGy/s. A cada 
pesagem pelo acelerador, a amostra recebeu a dose de $5 \mathrm{kGy}$. As amostras irradiadas por irradiação gama, foram tratadas no irradiador multipropósito de cobalto-60 do IPEN, a uma taxa de dose da fonte foi de 3,88 kGy. Essas amostras foram acondicionadas em frascos de polietileno com aproximadamente $500 \mathrm{~mL}$ de capacidade, e irradiadas em doses de 5, 10 e 20, kGy.

\subsection{Análises químicas do perfil composicional do caldo de cana-de-açúcar}

- Sólidos solúveis totais ( ${ }^{\mathrm{BR} I X)}$ - A determinação do teor de sólidos solúveis por cento de caldo foi realizada em refratômetro digital de bancada (Refractometer RFM712, Bellingham and Stanley, Ltd., Kent, UK), de leitura automática, com correção de temperatura e resolução máxima de $0,1^{\circ}$ Brix, devendo o valor final ser expresso a $20^{\circ} \mathrm{C}$ (CONSECANA, 2007).

- $\quad$ pH - Para a determinação do pH das amostras foi utilizado método de leitura direta em potenciômetro digital modelo pH METER TEC-2, Tecnal, São Paulo, Brasil (AOAC, 1980).

- Acidez total titulável - A acidez titulável foi determinada utilizando-se $\mathrm{NaOH}$ (Dinâmica, São Paulo, Brasil) 0,1 N, conforme metodologia recomendada pela AOAC (1980), foram pipetados $5 \mathrm{~mL}$ da amostra em balão de $50 \mathrm{~mL}$ completado posteriormente com água deionizada, o conteúdo do balão foi dispensado em Erlem Mayers onde foram adicionados 3 gotas do reagente fenolftaleína (Nuclear, São Paulo, Brazil), e o conteúdo foi tituado com $\mathrm{NaOH}$ (Dinâmica, São Paulo, Brasil) $0,1 \mathrm{~N}$ até a alteração de cor da amostra, em seguida foram anotados os valores gastos de $\mathrm{NaOH}$, e para quantificação dos teores de acidez total titulável em mg. $\mathrm{mL}^{-1}$ foram realizados cálculos descritos pelo método.

Vg.N.60.100

$$
A=
$$


Onde: $\mathrm{Vg}=$ volume gasto

$\mathrm{N}=$ normalidade do $\mathrm{NaOH}$

$\mathrm{V}=$ volume total titulado

\subsection{Composição de açúcares}

- $\quad$ Açúcares Redutores (AR) - Para quantificação de açúcares redutores foi utilizado o método calorimétrico do 3,5-dinitrosalicilico (DNS), descrito segundo Miller (1959), a amostra foi diluída em água deionizada na proporção 1/100 em $\mathrm{v} / \mathrm{v}$, foi então reirada uma alíquota de $0,5 \mathrm{~mL}$ dessa amostra e colocada em tubos de ensaio onde foram então adicionados $1,5 \mathrm{~mL}$ do reagente de DNS (Vetec, São Paulo, Brazil), levando ao aquecimento, por 5 minutos, resfriada em banho de gelo e analisado em espectrofotômetro (UV-Vis Spectrophotometer UV Mini 1240, Shimadzu Co., Japão) em absorbância a 540 nm. Os teores de açúcares redutores em $\mathrm{mg} \cdot \mathrm{mL}^{-1}$ foram calculados a partir de uma curva padrão realizada previamente. Para obtenção dos resultados em unidades por $100 \mathrm{~g}$ de caldo de cana-de-açúcar os resultados em $\mathrm{mg} \mathrm{mL}^{-1}$ foram divididos pela densidade do caldo.

- $\quad$ Açúcares Redutores Totais (ART) - Para análise de açúcares redutores totais a inversão da sacarose foi realizada por hidrólise ácida segundo o método Lane e Eynon (1923), utilizando-se $5 \mathrm{~g}$ de caldo de cana-de-açúcar e completando-se o volume final para $100 \mathrm{~mL}$ de água destilada. Da solução diluída foram retirados $20 \mathrm{~mL}$ e colocados em balão de $200 \mathrm{~mL}$ adicionado a $20 \mathrm{~mL}$ de água destilada. $\mathrm{O}$ balão foi aquecido a $65-70^{\circ} \mathrm{C}$, recebeu a adição de $10 \mathrm{~mL}$ de ácido clorídrico (Merck, São Paulo/SP). Após $20 \mathrm{~min}$, o sistema foi resfriado à temperatura ambiente e recebeu solução de hidróxido de sódio $20 \%$, até atingir seu ponto de viragem utilizando papel tornassol (J. Prolab, São Paulo, Brasil) como indicador. A solução então foi resfriada e foram completados os volumes do balão. Para realização do método completou-se a bureta de Mohr de $50 \mathrm{ml}$ de capacidade com solução hidrolisada, eliminando possíveis bolhas nas extremidades. Com a pipeta volumétrica transferiu-se $5 \mathrm{~mL}$ de Licor de Fehling para a câmara do Redutec com torneira da caldeira aberta e as demais fechadas; posteriormente adicionou-se a frio um volume da solução contida na bureta. 
Levando-se o Redutec a aquecimento, após a solução da câmara do Redutec entrar em ebulição, adicionou-se 3 gotas da solução de azul de metileno (Merck, São Paulo, Brazil) a 1\% e titulou-se gota-a-gota com a solução contida na bureta, até atingir o ponto de viragem da cor vermelho-tijolo, e anotou-se o volume gasto. O cálculo dos teores de açúcares redutores totais (ART) foi obtido a partir da equação representada a baixo. Para obtenção dos resultados em unidades por $100 \mathrm{~g}$ de caldo de cana-de-açúcar os resultados em g.100 $\mathrm{mL}^{-1}$ foram divididos pela densidade do caldo.

$$
\text { ART }=\left(\begin{array}{c}
496,4404 \\
\text { V.f }
\end{array}\right.
$$

Onde: $\mathrm{V}=$ volume gasto

$\mathrm{F}=$ fator de correção do licor de Fehling $(0,98)$

\subsection{Determinação de compostos fenólicos e flavonoides}

Para o procedimento das análises de teores de compostos fenólicos e flavonoides, as amostras foram preparadas antecipadamente segundo método descrito pela French Pharmacopeia (2002). Utilizou-se $5 \mathrm{~mL}$ de caldo de cana-deaçúcar misturado a $5 \mathrm{~mL}$ de solução de etanol a $80 \%$ (v/v) (Synth, São Paulo, Brasil) em tubos de ensaio, posteriormente os tubos foram colocados em banho de ultrassom por 10 min e centrifugados durante 20 min.

- Fenólicos totais - O conteúdo de fenólicos totais foi avaliado segundo Nozella (2001), com pequenas modificações. O teor de compostos fenólicos nas amostras foi determinado pelo método de Folin-Ciocalteau utilizando $100 \mu \mathrm{L}$ dessa solução, misturados a $900 \mu \mathrm{L}$ de água deionizada, em seguida adicionouse uma alíquotas de 0,5 mL dos reagentes de Folin-Ciocalteau (Dinâmica, São Paulo/Brazil) diluído 1:10 (v/v) com água deionizada e 2,5 mL de solução a 4\% $(\mathrm{m} / \mathrm{v})$ de $\mathrm{Na}_{2} \mathrm{CO}_{3}$ (Dinâmica, São Paulo, Brazil) após 40 min foram feitas as leituras em espectrofotômetro (UV-Vis Spectrophotometer UV Mini - 1240, Shimadzu Co., Japão) a $725 \mathrm{~nm}$. O conteúdo de fenólicos totais foi expressos como mg. $\mathrm{mL}^{-1}$ (em equivalentes de ácido tânico). Para obtenção dos resultados 
em unidades por $100 \mathrm{~g}$ de caldo de cana-de-açúcar os resultados em $\mathrm{mg} \cdot \mathrm{mL}^{-1}$ foram divididos pela densidade do caldo.

- $\quad$ Flavonoides totais - Para avaliação dos conteúdos de flavonoides totais segundo Park et al. (1995), com pequenas modificações Os conteúdos de flavonoides totais foram determinados a partir de uma mistura de $0,5 \mathrm{~mL}$ das amostras, 4,3 mL de solução 80\% de etanol (Synth, São Paulo, Brasil), 0,1 mL de solução a $10 \%(\mathrm{~m} / \mathrm{v})$ de $\mathrm{Al}\left(\mathrm{NO}_{3}\right)_{3}$ (Syntth, São Paulo, Brasil) e 0,1 mL de solução $1 \mathrm{M}$ de acetato de potássio. Após $40 \mathrm{~min}$, à temperatura ambiente, a leitura dos valores de absorbância foi feita em espectrofotômetro (UV-Vis Spectrophotometer UV Mini - 1240, Shimadzu Co., Japão) a 415 nm, sendo que o conteúdo de flavonoides foi calculado contra curva de calibração de quercetina (mg.mL ${ }^{-1}$ ). Para obtenção dos resultados em unidades por $100 \mathrm{~g}$ de caldo de cana-de-açúcar os resultados em mg. $\mathrm{mL}^{-1}$ foram divididos pela densidade do caldo.

\subsection{Determinação dos índices de cor ICUMSA}

A determinação do índice de cor das amostras foi realizada segundo o método da comissão internacional para unificação dos métodos de analise açucareira (ICUMSA, 1994) ajustada para amostras liquidas. Para tanto o pH das amostras foram ajustados para 5,5 $\pm 0,05$ e o Brix para 1,25 com água deionizada. As soluções foram filtradas em membrana de 0,45 $\mu \mathrm{m}$. Em seguida foi determinada a absorbância em espectrofotômetro (UV-Vis Spectrophotometer UV Mini - 1240, Shimadzu Co., Japão) a $420 \mathrm{~nm}$, usando água deionizada como solução de referência. A cor foi determinada a partir do seguinte equacionamento. Cor ICUMSA $(420 \mathrm{~nm})=[(1000-\log \mathrm{T}) /(\mathrm{b} \times \mathbf{c})]$, onde, T é a transmitância da solução amostra lida; b é o comprimento da cela de absorção, em cm; e c é a concentração da amostra diluída, em $\mathrm{g} / \mathrm{mL}$, calculada em função da concentração (Brix) e densidade, conforme a equação: $\mathbf{c}=($ Brix $\times$ densidade $) / 100$.

\subsection{Análise cromatográfica de açúcares no caldo de cana-de-açúcar}

Para as análises cromatográficas foram utilizados um cromatógrafo líquido modelo UFLC Shimadzu vinculado a um detector do tipo Evaporative Light Scattering Detection - ELSD-LT II e as análises foram conduzidas por método 
isocrático segundo Shimadzu Aplications $\mathrm{News}^{2}$, (2011) com pequenas modificações.

As amostras de caldo de cana-de-açúcar foram clarificadas utilizando 2,82 $\mathrm{g}$ de subacetato de chumbo para cada $100 \mathrm{~mL}$ de caldo, foram diluídas na fração $1 / 10(v / v)$ e foram filtradas em unidades filtrantes Durapore ${ }^{\circledR} 0,45 u$ de poro, $13 \mathrm{~mm}$ não estéril Millipore do Brasil. Foram realizadas duas corridas para cada amostra sendo que na primeira corrida se analisou os açucares redutores glicose e frutose e em uma segunda corrida avaliou-se o perfil da sacarose contida no caldo de cana-de-açúcar, assim como foram realizadas as curvas padrões para posterior quantificação dos compostos avaliados.

Utilizou-se uma coluna do tipo $\mathrm{NH}_{2} \mathrm{P}-50$ 4E (250 mm L x $4.6 \mathrm{~mm}$ ID) Shodex Packed, como fase móvel foram utilizados acetonitrila Tedia Company Inc. e água Milique nas proporções $7 / 3(\mathrm{v} / \mathrm{v} \%)$, a um fluxo contínuo de $1 \mathrm{~mL} / \mathrm{min}$ sendo a temperatura da coluna $30^{\circ} \mathrm{C}$. Para o detector Evaporative Light Scattering Detection foram utilizadas as condições de $35^{\circ} \mathrm{C}$ de temperatura, $350 \mathrm{kPa}$ de pressão para o nebulizador de gás $\mathrm{N}_{2}$, sendo que para determinação de frutose e glicose foram utilizados o ganho de 7 e volume de injeção de $20 \mu \mathrm{L}$ e para determinação de sacarose foram utilizados ganho 3 e volume de injeção $5 \mu \mathrm{L}$.

\subsection{Análises Estatísticas}

Os dados foram randomizados em blocos casualizados e avaliados pelo Teste de Tukey $(p<0,05)$, para determinar a diferença estatística entre as médias, usando pacote estatístico SAS (Statistical Analysis System) versão 9.0. Todos os resultados foram expressos como a média de três repetições, no mínimo, e expressos como a média \pm desvio padrão. 


\section{RESULTADOS E DISCUSSÃO}

As amostras utilizadas para clarificação com radiação gama e por elétrons acelerados foram extraídas em safras e épocas distintas, portanto, apresentam características e perfis diferentes para os parâmetros avaliados. No entanto ambos os tratamentos com radiação resultaram em um comportamento semelhante.

\subsection{Perfil composicional do caldo de cana-de-açúcar}

Foram analisados parâmetros como Brix, pH e acidez total titulável que compreendem o perfil químico composicional do caldo de cana-de-açúcar. Os resultados estão demonstrados nas Tabelas 1 e 2 .

Tabela 1 - pH e acidez total titulável para as amostras controle e irradiadas com feixe de elétrons e em fonte de cobalto-60 nas dose 5, 10 e 20 kGy.

\begin{tabular}{|c|c|c|c|c|}
\hline \multirow{2}{*}{ Amostra } & \multicolumn{2}{|c|}{$\mathrm{pH}$} & \multicolumn{2}{|c|}{ Acidez total $\left(\mathrm{mg} \mathrm{mL}^{-1}\right)$} \\
\hline & $\begin{array}{l}\text { Feixe de } \\
\text { elétrons }\end{array}$ & Cobalto-60 & $\begin{array}{l}\text { Feixe de } \\
\text { elétrons }\end{array}$ & Cobalto-60 \\
\hline Controle & $5,30 \pm 0,05^{c}$ & $5,30 \pm 0,04^{b}$ & $117,2 \pm 13,5^{a}$ & $93,6 \pm 4,30^{a}$ \\
\hline $5 \mathrm{kGy}$ & $5,30 \pm 0,05^{c}$ & $5,30 \pm 0,04^{b}$ & $106,8 \pm 2,1^{\mathrm{ab}}$ & $87,6 \pm 0,01^{b}$ \\
\hline $10 \mathrm{kGy}$ & $5,37 \pm 0,06^{b}$ & $5,26 \pm 0,02^{c}$ & $103,2 \pm 2,1^{\mathrm{ab}}$ & $82,0 \pm 5,00^{b c}$ \\
\hline $20 k G y$ & $5,43 \pm 0,08^{a}$ & $5,37 \pm 0,06^{\mathrm{a}}$ & $97,2 \pm 2,4^{b}$ & $80,4 \pm 3,20^{c}$ \\
\hline
\end{tabular}

Médias de $\mathrm{n}=3 \pm$ desvio padrão, letras iguais na vertical, não diferem estatisticamente pelo Teste de Tukey a $5 \%$ de significância.

A partir da Tabela 1 temos que as amostras que sofreram ambos os tipos de tratamento, aumentaram significativamente $(p<0,05)$ os níveis de $\mathrm{pH}$ da amostra irradiada na maior dose (20 kGy) em relação as demais amostras. No entanto, trabalhos mostraram que valores de $\mathrm{pH}$ podem diminuir à medida que a dose de irradiação aumenta uma vez que a radiação ao interagir com as moléculas de sacarose, glicose e frutose fragmentam essas moléculas para a 
formação de ácidos, conforme já demonstrado por Oh et al. (2006). Fato observado em trabalhos como o de Wilska-Jeszka e Skorupinska (1975) que observaram diminuição no $\mathrm{pH}$ em suco de tomate e dos xaropes de groselha preta e vermelha com o aumento das doses de radiação. Ou ainda, em trabalhos realizados com açúcares invertidos irradiados em aceleradores de elétrons e irradiação gama onde houve redução do $\mathrm{pH}$ das amostras irradiadas em relação ao controle, fato este que sugere que a radiação ao interagir com as moléculas de açúcares fragmentam essas moléculas com a formação de ácidos (PODADERA, 2007).

$\mathrm{O}$ fato do $\mathrm{pH}$ do caldo não sofrer redução em seus teores pode se mostrar como fator positivo uma vez que, em meio ácido pode ocorrer a inversão da sacarose a glicose e frutose, presentes no caldo de cana-de-açúcar, encadeando uma série de reações de desidratação que podem resultar na formação de compostos coloridos, indesejados (RIFFER, 1988). O que pode afetar diretamente a pureza, refletindo negativamente na recuperação do açúcar pela fábrica acarretando em reações que aumentam a cor do açúcar e consequentemente depreciam sua qualidade (RIPOLI e RIPOLI, 2004). Visto que para Payne (1989), os compostos coloridos resultam da reação entre aminoácidos e açúcares redutores, da decomposição dos açúcares e de muitas reações do tipo condensação.

$\mathrm{O}$ aumento do $\mathrm{pH}$ foi evidenciado quando avaliados os teores de acidez total titulável para as quais observou-se redução dos seus teores indicando que as amostras irradiadas na maior dose diminuíram sua acidez em ambos os tratamentos ou seja, tornaram-se menos ácida, como pode ser visto na Tabela 1. 
Tabela 2 - Variação dos sólidos solúveis (Brix) para as amostras controle e irradiadas com feixe de elétrons e em fonte de cobalto-60 nas doses 5, 10 e 20 kGy.

\begin{tabular}{|c|c|c|}
\hline \multirow[b]{2}{*}{ Amostra } & \multicolumn{2}{|c|}{ Brix(\%) } \\
\hline & Feixe de elétrons & Cobalto-60 \\
\hline Controle & $19,2 \pm 0,05^{\mathrm{a}}$ & $13,2 \pm 0,04^{a}$ \\
\hline 5 kGy & $19,2 \pm 0,05^{\mathrm{a}}$ & $13,2 \pm 0,04^{a}$ \\
\hline 10 kGy & $19,2 \pm 0,05^{\mathrm{a}}$ & $13,1 \pm 0,05^{b}$ \\
\hline 20 kGy & $19,1 \pm 0,06^{b}$ & $13,0 \pm 0,06^{c}$ \\
\hline
\end{tabular}

Médias de $\mathrm{n}=3 \pm$ desvio padrão, letras iguais na vertical, não diferem estatisticamente pelo Teste de Tukey a $5 \%$ de significância.

Para avaliação de sólidos solúveis (Brix) observado na Tabela 2, houve uma redução significativa $(p<0,05)$, em seus teores, das amostras irradiadas com a maior dose (20 kGy) em relação as demais amostras tanto para irradiação com feixe de elétrons como em fonte de cobalto-60. Trabalhos realizados com pêssegos irradiados, em fonte de cobalto-60 obtiveram também redução do Brix (LEVIT, 2012), o que sugeriu a possibilidade de interação da radiação com monossacarídeos e dissacarídeos presentes nos pêssegos.

No entanto, para Podadera (2007), em trabalho realizado com soluções açucaradas, observou que estas amostras ao sofrerem tratamentos de radiação aumentam seu grau Brix, o que pode indicar que as moléculas de açúcar presentes em solução ao receberem a energia proveniente da radiação podem sofrer quebras, gerando moléculas de menor massa molecular, como por exemplo, ácidos, aumentando a concentração de sólidos solúveis. Porém não foi observado neste trabalho o aumento de grau de Brix das soluções irradiadas quando comparadas ao controle.

\subsection{Composição de açúcares no caldo de cana-de-açúcar}

Os teores de açúcares do caldo de cana-de-açúcar avaliados através das análises de açúcares redutores (AR), açúcares redutores totais (ART) estão expressos na Tabela 3. Há diferenças entre as amostras controle dos tratamentos 
de irradiação por fonte de cobalto-60 e feixe elétrons ocorreu devido às amostras utilizadas serem de safras e épocas diferentes.

Tabela 3 - Variação dos açúcares redutores e açúcares redutores totais (ART) em $\mathrm{g} / 100 \mathrm{~g}$ de caldo de cana-de-açúcar.
ART (g.100g $\left.{ }^{-1}\right)$
AR $\left(\right.$ g.100 $\left.\mathrm{g}^{-1}\right)$

Amostras

\begin{tabular}{|c|c|c|c|c|}
\hline (9) & $\begin{array}{l}\text { Feixe de } \\
\text { elétrons }\end{array}$ & Cobalto-60 & $\begin{array}{l}\text { Feixe de } \\
\text { elétrons }\end{array}$ & Cobalto-60 \\
\hline Controle & $32,8 \pm 0,3^{a}$ & $11,5 \pm 0,4^{\mathrm{a}}$ & $0,65 \pm 0,03^{c}$ & $2,67 \pm 0,08^{d}$ \\
\hline 5 kGy & $32,9 \pm 0,2^{a}$ & $11,4 \pm 0,1^{a}$ & $0,66 \pm 0,03^{c}$ & $3,47 \pm 0,14^{b}$ \\
\hline 10 kGy & $33,3 \pm 0,1^{a}$ & $11,3 \pm 0,2^{a}$ & $0,78 \pm 0,01^{b}$ & $3,09 \pm 0,09^{c}$ \\
\hline 20 kGy & $32,2 \pm 0,2^{b}$ & $11,4 \pm 0,2^{a}$ & $0,95 \pm 0,05^{a}$ & $4,08 \pm 0,14^{a}$ \\
\hline
\end{tabular}

Médias de $\mathrm{n}=3 \pm$ desvio padrão, letras iguais na vertical, não diferem estatisticamente pelo Teste de Tukey a $5 \%$ de significância.

Para teores de açúcares redutores totais mostrado na Tabela 3 observamos uma redução significativa ao nível de $5 \%$ de probabilidade da amostra irradiada em acelerador de elétrons na maior dose (20 kGy) em relação às demais amostras. Para o tratamento com radiação gama não houve diferença significativa entre as amostras tratadas e controle. Trabalhos realizados em matrizes açucaradas irradiadas mostraram também estabilidade nas concentrações de açúcares totais das amostras como no trabalho realizado por Oliveira (2007) onde seus teores de açúcares redutores e de carboidratos totais presentes no caldo de cana-de-açúcar puro ou adicionado de suco de frutas submetido à radiação gama não apresentaram diferença significativa entre o produto in natura e os processados. Outros estudos como o de Van Zeller et al. (1984), estudando a conservação de xarope de cana-de-açúcar pelo emprego da radiação gama, também não observaram mudanças significativas nos teores de glicose, frutose e sacarose do xarope quando irradiado com doses de até $40 \mathrm{kGy}$, ou ainda, por Watanabe e Sato (1980) que observaram estabilidade na concentração de açúcares totais presentes em xarope e mosto de cana-de-açúcar submetidos à radiação gama com doses de 30 e 40 kGy, respectivamente.

Os teores de açúcares redutores das amostras irradiadas com feixe de elétrons foram afetados significativamente, ao nível de 5\%, aumentado os teores 
nas amostras de 10 e 20 kGy em relação as amostras controle e 5 kGy, como pode ser visto na Tabela 3. Para as amostras irradiadas em fonte de cobalto-60 houve aumento nos teores de açúcares redutores das amostra irradiadas em relação ao controle, sendo que o maior teor encontrado foi da amostra que recebeu maior dose (20 kGy). Segundo Podadera (2007) em seu trabalho realizado com açúcar invertido, os teores de açúcares redutores das amostras irradiadas também aumentaram em relação às amostras controles, em seu trabalho as amostras irradiadas com feixe de elétrons o aumento maior de glicose e frutose ocorreu na amostra que recebeu 30 kGy, enquanto na radiação gama o maior aumento ocorreu na amostra de 50 kGy.

O fato de haver aumento dos teores de açúcares redutores pode provavelmente estar relacionado com o aumento de outros compostos de caráter redutor presentes no caldo de cana-de-açúcar visto que a partir dos resultados obtidos para as análises de açúcares em cromatográfico liquido de alta eficiência o aumento observado para açúcares redutores (glicose e frutose) não se mostram tão significativos como pode ser observado na Tabela 4.

Análises cromatográficas de quantificação de açúcares foram realizadas somente para as amostras irradiadas com feixe de elétrons e os resultados estão expressos na Tabela 4. Por se tratar de um método preciso e que já havia sido testado anteriormente mostrando resultados sem variações quando realizado em triplicatas, optou-se realizar somente uma corrida cromatográfica para cada amostra, para evitar gastos desnecessários com reagentes, desgaste do equipamento além de reduzir a formação de resíduo tóxico. 
Tabela 4 - Teores de açúcares (frutose, glicose e sacarose) do caldo de cana-deaçúcar quantificado a partir cromatografia líquida para as amostras controle e irradiadas em acelerador de elétrons. Valores expressos em g de açúcar/100 g de amostra.

\begin{tabular}{|c|c|c|c|}
\hline Amostras & Frutose $\left(\mathrm{g} .100 \mathrm{~g}^{-1}\right)$ & Glicose $\left(\mathrm{g} .100 \mathrm{~g}^{-1}\right)$ & Sacarose $\left(\mathrm{g} .100 \mathrm{~g}^{-1}\right)$ \\
\hline Controle & 0,227 & 0,212 & 14,47 \\
\hline 5 kGy & 0,234 & 0,184 & 14,37 \\
\hline 10 kGy & 0,242 & 0,192 & 14,25 \\
\hline $20 \mathrm{kGy}$ & 0,287 & 0,220 & 14,17 \\
\hline
\end{tabular}

Os resultados representam uma única corrida cromatográfica realizada para cada amostra devido à precisão do método utilizado.

As Figuras 7 e 8 representam os perfis cromatográficos dos açúcares glicose, frutose e sacarose. Os teores glicose e frutose encontrados no caldo de cana-de-açúcar aproximam-se respectivamente de 0,4 e 0,2\% do caldo, já os teores de sacarose são de aproximadamente $17 \%$ de sacarose segundo Payne (1989). Essa grande diferença nas concentrações de açúcares redutores e sacarose encontrado no caldo fez com que não fosse possível os açúcares serem analisados em uma mesma corrida cromatográfica, sendo então necessário identificá-los em diferentes condições. Primeiramente foram identificados os açúcares redutores que se encontram em menor quantidade no caldo, e seus perfis cromatográficos estão representados na Figura 7, e em seguida assumindo novas condições do cromatográfo liquido e com maior diluição identificamos a sacarose cujo perfil cromatográfico está representado na Figura 8.

A partir das analises cromatográficas observou um aumento dos teores de açúcares redutores, mais evidenciado da amostra irradiada na maior dose (20kGy) em relação ao controle, como já mostrado, para análise de açúcar redutor por DNS anteriormente. Para teores de sacarose observou-se uma pequena redução das amostras irradiadas em relação ao controle. No entanto esta redução nos teores de sacarose não se mostrou significativa, prejudicando a composição do caldo. Embora as análises mostrem um aumento dos teores de açúcares redutores, o trabalho manteve seu propósito de redução de cor do caldo, mesmo sabendo que açúcares redutores se envolvem e reações que podem aumentar a cor desse caldo e consequentemente do açúcar bruto gerado. 

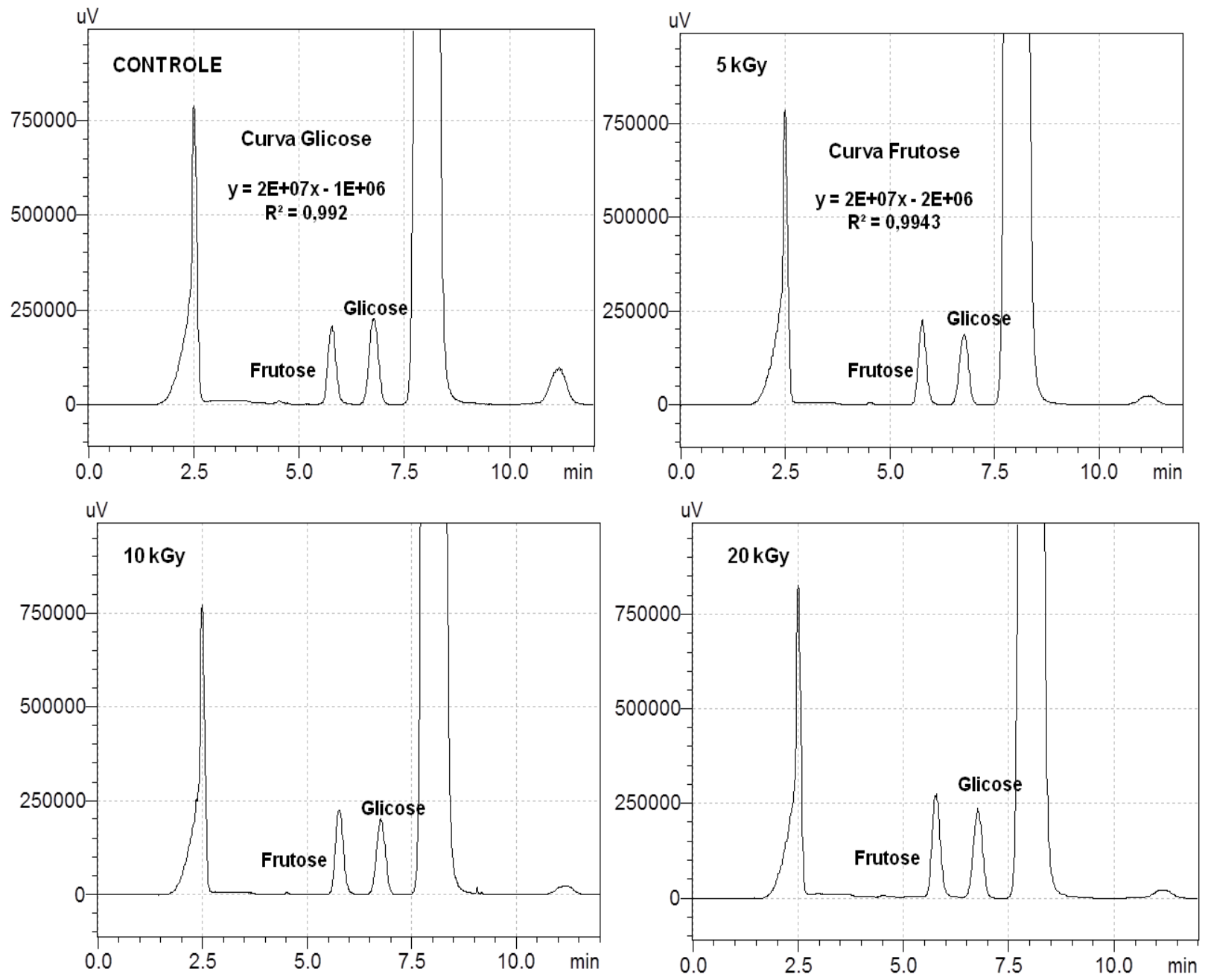

Figura 7 - Cromatogramas dos açúcares redutores frutose e glicose das amostras controle e irradiadas em feixe de elétrons nas doses 5, 10 e 20 kGy. 

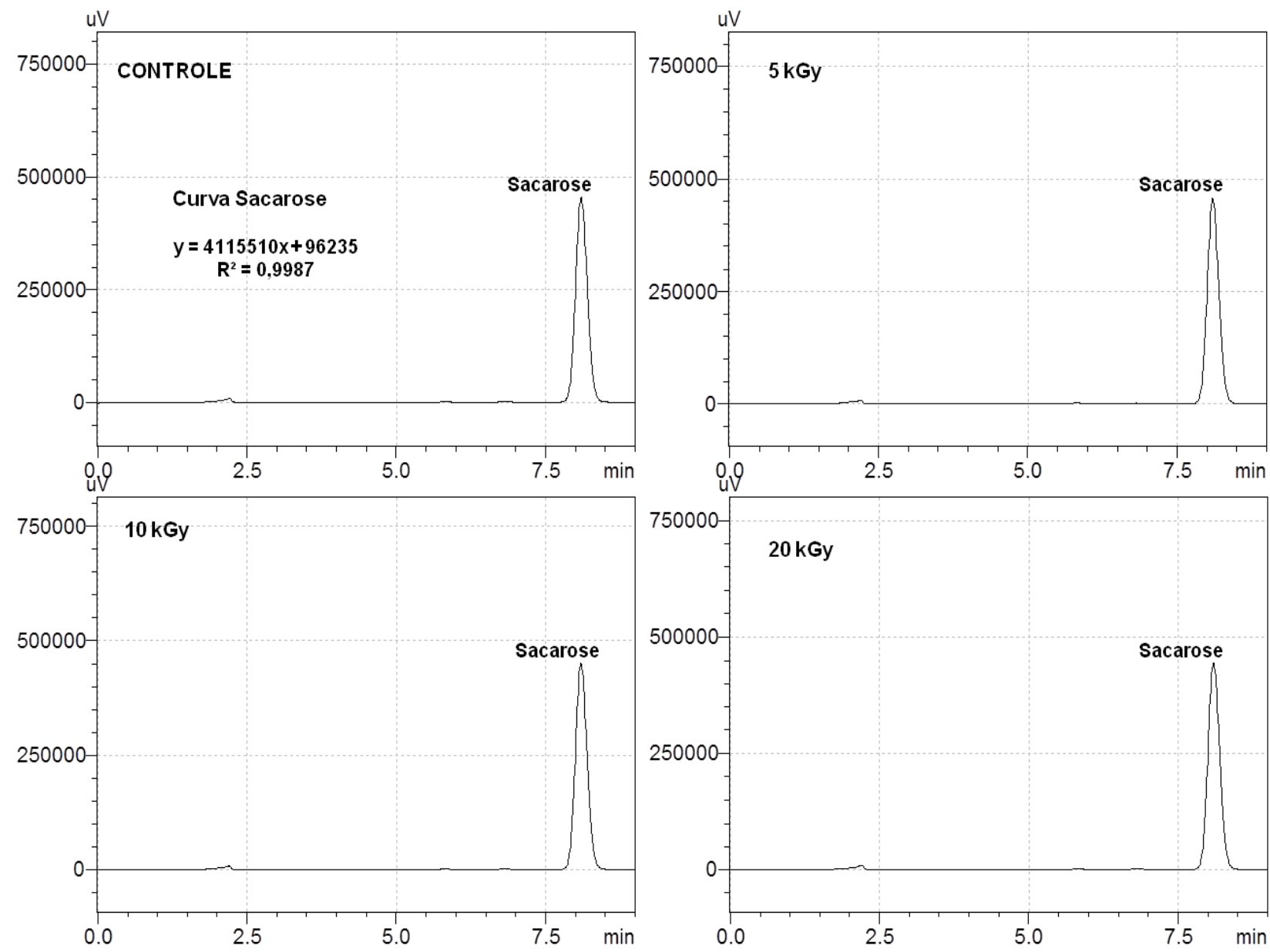

Figura 8 - Cromatogramas de sacarose das amostras controle e irradiadas em feixe de elétrons nas doses 5, 10 e 20 kGy.

\subsection{Teores de compostos fenólicos e flavonoides}

Foram também avaliados compostos fenólicos e flavonoides visto que para alguns autores como Clarke e Legendre (1999), a coloração do caldo de cana-de-açúcar tem sua origem principalmente nesses compostos dentre outros, que podem refletir na cor final do produto.

Para teores de compostos fenólicos mostrados na Tabela 5, as amostras irradiadas em acelerador de elétrons, diferenciaram-se estatisticamente $(p<0,05)$ entre si, sendo que quanto maior a taxa de dose aplicada maiores foram os teores de compostos fenólicos encontrados, isto ocorre muito provavelmente pela maior taxa de dose aplicada no método de 22,38 kGy/s quando comparada a taxa de dose do tratamento realizado por radiação gama de cerca de 3,88 kGy/h. Para as amostras tratadas em fonte de cobalto-60 observou-se um aumento estatisticamente significativo $(p<0,05)$ das amostras que sofreram radiação em 
relação ao controle, sendo que as amostras irradiadas a 5 e 10 kGy não se diferenciaram estatisticamente umas das outras porém na dose de 20 kGy houve o maior teor destes compostos. Para teores de compostos flavonoides houve diferença significativo ao nível de $5 \%$ de probabilidade da amostra controle em relação às amostras irradiadas, sendo que os teores de compostos flavonoide aumentaram nas amostras irradiadas, no tratamento com feixe de elétrons. Já as amostras irradiadas em fonte de cobalto-60 houve redução significativa dos teores de flavonoides, da amostra controle em relação às amostras irradiadas a 5 e 10 kGy.

Aumento de teores de compostos fenólicos e flavonoides têm sido relatados em grãos de amendoim irradiados visto que este processo pode tornar os compostos fenólicos mais disponíveis a partir de doses de 15 e 10 kGy (CAMARGO, 2011), o aumento dos teores de compostos fenólicos se dá provavelmente pela quebra desses compostos fenólicos e consequente formação de ácidos fenólicos que se tornam mais disponíveis.

Clarke et al. (1984) relatam que os compostos fenólicos e flavonoides são considerados como aqueles que mais afetam a cor do caldo de cana-deaçúcar, tendo sido responsáveis por 60 a $75 \%$ da cor do açúcar. Assim, a presença de compostos coloridos ou precursores de cor no açúcar pode desqualificá-lo pela falta de homogeneidade e pureza dos grãos, problemas relacionados com a dificuldade na cristalização (LEITE, 2000). De acordo com Stupiello (2002) e Simoni et al. (2006), tem sido observado nas usinas que a matéria-prima que mostra maior teor de compostos fenólicos, acaba levando mais compostos precursores de cor no processo de fabricação do açúcar. Estudos realizados pela Fermentec (2005) em 30 amostras de açúcar de 11 usinas diferentes revelaram que quanto maior a concentração de fenólicos maior será a cor ICUMSA. 
Tabela 5 - Variação dos compostos fenólicos e flavonoides totais das amostras controle e irradiadas em acelerador de elétrons e em fonte de cobalto-60.

Fenólicos $\left(\mathrm{mg}^{1} \mathbf{1 0 0 g}^{-1}\right)$

\begin{tabular}{lllllll}
\cline { 5 - 6 } Amostra & $\begin{array}{l}\text { Feixe de } \\
\text { elétrons }\end{array}$ & Cobalto-60 & & $\begin{array}{l}\text { Feixe de } \\
\text { elétrons }\end{array}$ & Coblato-60 \\
\cline { 1 - 1 } \cline { 5 - 7 } Controle & & $9,7 \pm 0,1^{\mathrm{d}}$ & $4,24 \pm 0,17^{\mathrm{c}}$ & & $6,9 \pm 0,4^{\mathrm{b}}$ & $1,18 \pm 0,04^{\mathrm{a}}$ \\
$5 \mathrm{kGy}$ & & $10,6 \pm 0,4^{\mathrm{c}}$ & $5,76 \pm 0,16^{\mathrm{b}}$ & & $8,1 \pm 0,4^{\mathrm{a}}$ & $1,07 \pm 0,07^{\mathrm{ab}}$ \\
$10 \mathrm{kGy}$ & & $12,1 \pm 0,1^{\mathrm{b}}$ & $6,03 \pm 0,25^{\mathrm{b}}$ & & $9,1 \pm 0,5^{\mathrm{a}}$ & $1,02 \pm 0,04^{\mathrm{b}}$ \\
$20 \mathrm{kGy}$ & & $13,1 \pm 0,3^{\mathrm{a}}$ & $6,66 \pm 0,22^{\mathrm{a}}$ & & $8,9 \pm 0,4^{\mathrm{a}}$ & $0,85 \pm 0,02^{\mathrm{c}}$
\end{tabular}

Flavonoides $\left(\mathrm{mg}^{\mathrm{1000}} \mathrm{g}^{-1}\right)$

Médias de $n=3 \pm$ desvio padrão, letras iguais na vertical, não diferem estatisticamente pelo Teste de Tukey a $5 \%$ de significância.

\subsection{Avaliação da cor ICUMSA do caldo de cana-de-açúcar}

Um dos parâmetros utilizados na qualificação e comercialização do açúcar para exportação é a medida da sua cor sendo que quanto mais baixa a unidade ICUMSA (U.I.), mais claro ou mais branco é o açúcar gerado (SIMIONI et al., 2006). A partir da Tabela 6 observamos que a cor ICUMSA variou de 3268 U.I. a 1669 U.I., para amostras tratadas em acelerador de elétrons e de 7628 U.I. a 5303 U.I. para o tratamento realizado em fonte de cobalto-60, mostrando que ambos os processos de radiação possuem capacidade oxidativa de redução da coloração do caldo de cana-de-açúcar.

Tabela 6 - Cor ICUMSA das amostras controle e irradiadas com feixe de elétrons e em fonte de cobalto-60 nas doses 5, 10 e 20 kGy.

Cor ICUMSA (U.I)

\begin{tabular}{|c|c|c|}
\hline Amostra & Feixe de elétrons $(\text { IRC) })^{\star \star}$ & Cobalto-60 (IRC) ${ }^{\star \star}$ \\
\hline Controle & $3268 \pm 391^{a}$ (n.d. $)^{*}$ & $7628 \pm 1608^{a}(\text { n.d })^{\star}$ \\
\hline $5 \mathrm{kGy}$ & $1894 \pm 134^{b}(42 \%)$ & $5695 \pm 209^{\mathrm{ab}}(25,3 \%)$ \\
\hline $10 \mathrm{kGy}$ & $1766 \pm 249^{b}(45 \%)$ & $5627 \pm 377^{\mathrm{ab}}(26,2 \%)$ \\
\hline 20 kGy & $1669 \pm 276.0^{\mathrm{b}}(49 \%)$ & $5303 \pm 173^{b}(30,5 \%)$ \\
\hline
\end{tabular}

Médias de $\mathrm{n}=3 \pm$ desvio padrão, letras iguais na vertical, não diferem estatisticamente pelo Teste de Tukey a $5 \%$ de significância.

*número não determinável,

** índice de redução de cor do caldo de cana-de-açúcar. 
Os resultados observados na Tabela 6 mostram que houve uma diminuição estatisticamente significativa $(p<0,05)$ da coloração do caldo de canade-açúcar da amostra controle em relação às amostras irradiadas em acelerador de elétrons a 5, 10 e 20 kGy. Para as amostras tratadas em fonte de cobalto-60 os resultados foram afetados significativamente $(p<0,05)$ da amostra controle em relação à amostra irradiada à 20 kGy. Para melhor interpretação da redução de cor ICUMSA do caldo de cana-de-açúcar os resultados estão representados na Figura 9.

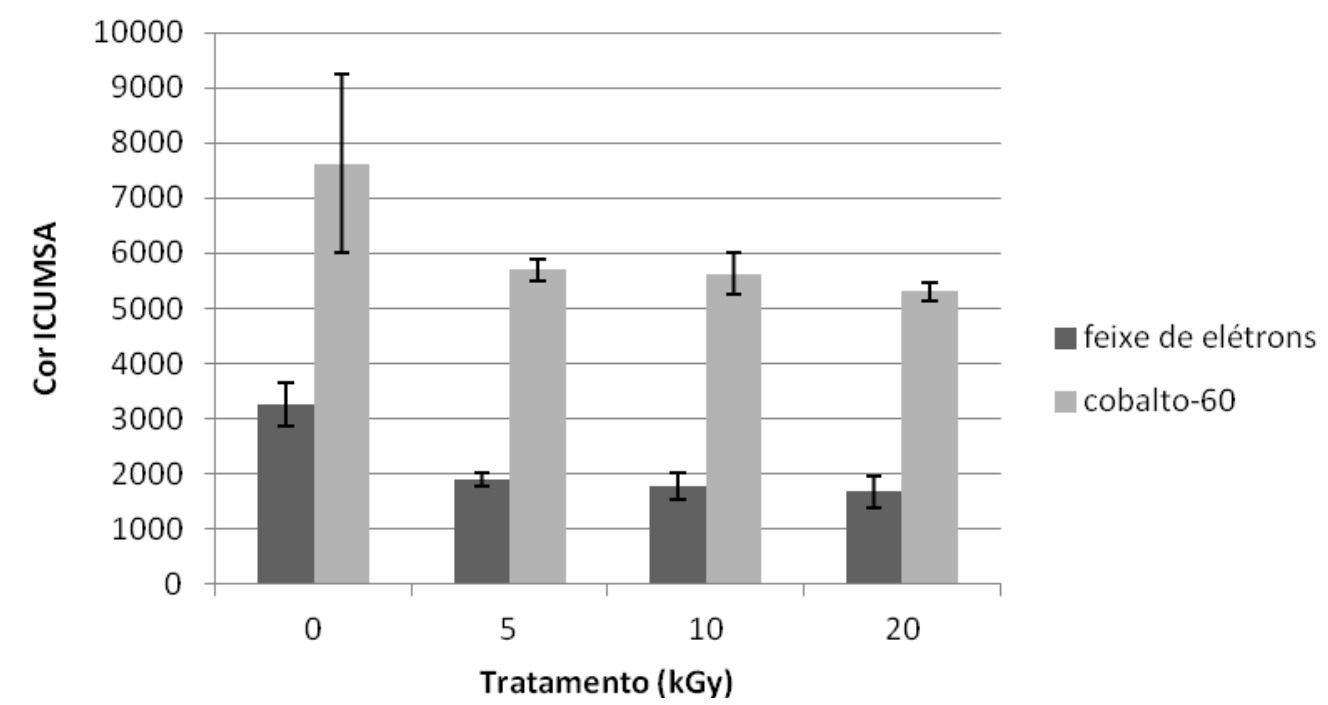

Figura 9. Variação da cor ICUMSA do caldo de cana-de-açúcar tratado por radiação gama e por feixe de elétrons, nas doses 5, 10 e 20 kGy.

A partir dos índices de redução de cor (IRC) que estão demonstrados na tabela 6, observamos que o maior índice de redução de cor foi encontrado no tratamento realizado com irradiação a partir de acelerador de elétrons, representado na amostra que recebeu maior dose (20 kGy), por uma redução de $49 \%$. Sendo que a amostra irradiada por radiação gama à 20 kGy obteve uma redução de $30 \%$. O fato do tratamento realizado com a radiação por feixe de elétrons apresentar maior índice de redução de cor ICUMSA ocorreu muito provavelmente por este tipo de radiação obter maior taxa de dose dada em 22,38 kGy/s, quando comparado a irradiação gama de 3,88 kGy/h. Mostrando então, a 
maior eficiência do tratamento com feixe de elétrons, em redução da cor em caldo de cana-de-açúcar comparado a radiação gama e quando comparado ao método utilizado pelas usinas, a sulfitação, que em média obtêm uma redução de cor ICUMSA do caldo de cana-de-açúcar de aproximadamente 42\% (dados fornecido por uma usina real).

As Figuras 10 e 11 nos mostram que a redução de cor do caldo de cana-de-açúcar pôde ser percebida visualmente após ambos os tratamentos com radiação já em laboratório. Redução de cor já havia sido observada por Wotton et al. (1988) em grãos de arroz, submetidos a radiação gama em doses de 10 kGy, sem que ainda houvesse alterações na composição química, esta mudança na coloração foi atribuída a oxidação de compostos fenólicos em melanoidinas. Amostras de sucos de laranja irradiados apresentaram uma coloração amarelo mais claro e maior brilho que o suco controle (VERRUMA-BERNARDI e SPOTTO, 2003), ou ainda em matrizes açucaradas por Podadera (2007), em seu trabalho, realizado com açúcar invertido, onde as amostras após sofrerem a irradiação, perdiam a cor característica do açúcar invertido, que é amarelo ficando transparente.

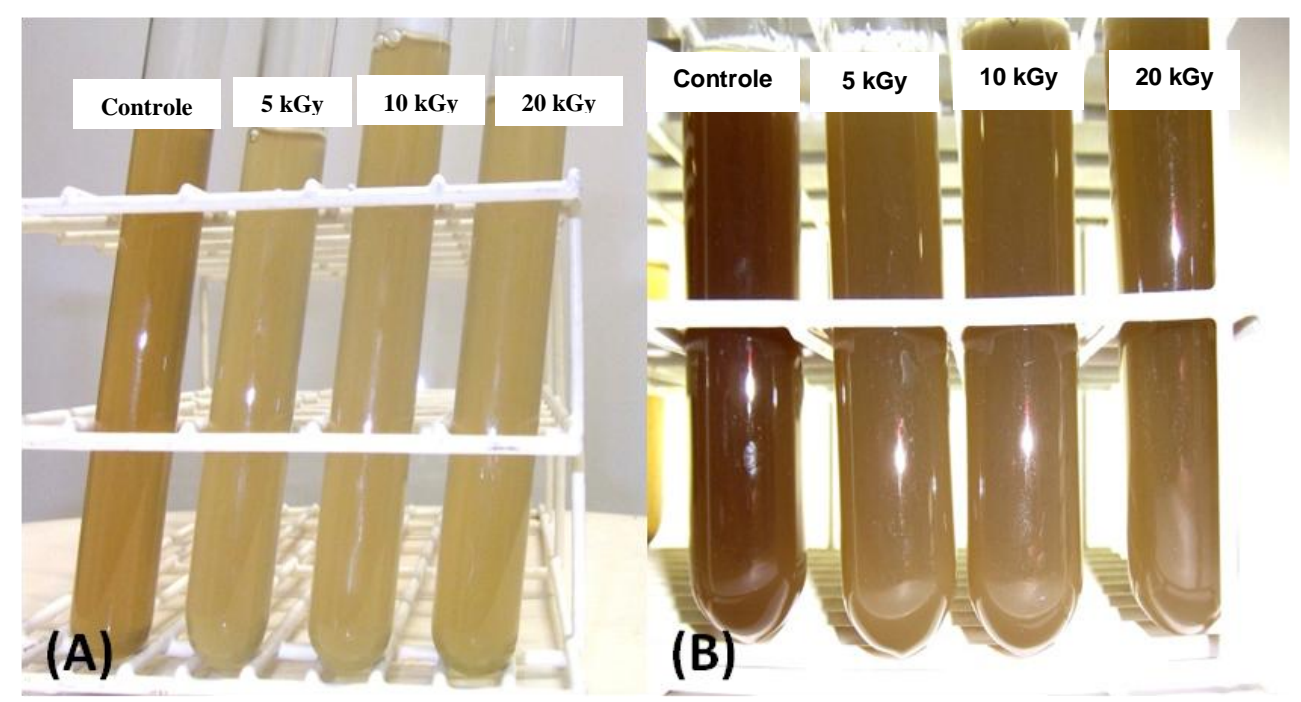

Figura 10 - Amostras de caldo de cana-de-açúcar filtradas em papel filtro qualitativo FRMA cod. FRF1500 × 50000014, 12,5 $\varnothing$ (A) e amostra bruta (B) controle e irradiadas nas doses de 5, 10 e 20 kGy em acelerador de elétrons. 


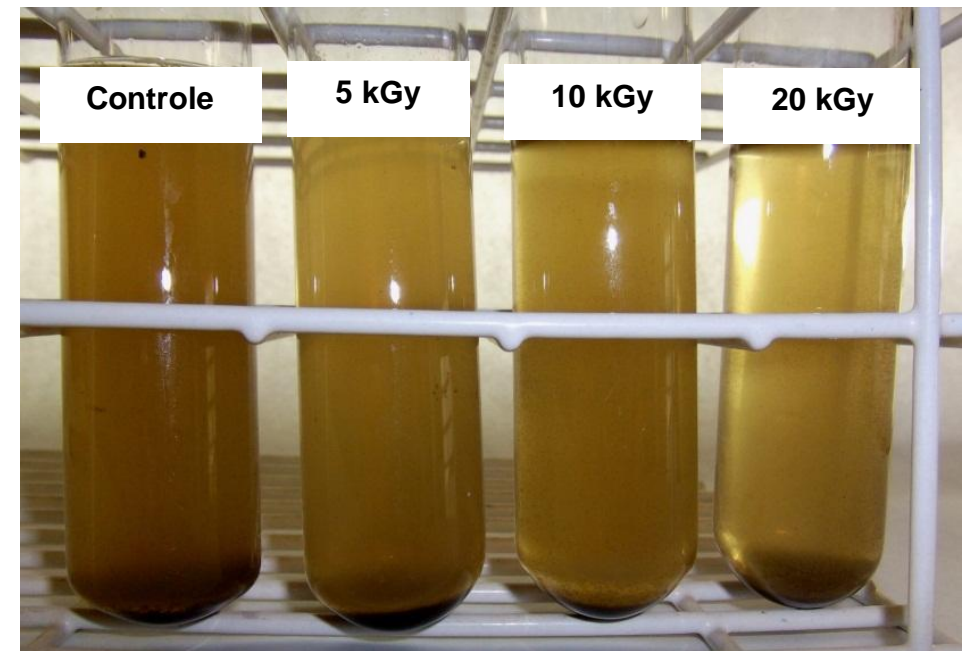

Figura 11 - Amostras brutas de caldo de cana-de-açúcar irradiados em fonte de coblato-60 nas doses 5, 10 e 20 kGy. 


\section{CONCLUSÂO}

Observou-se que embora haja alterações estatísticas entre as amostras controle e as que sofreram radiação para os parâmetros avaliados como pH, brix e acidez; estes não comprometeram as características do caldo de cana-deaçúcar. Concluiu-se ainda que houve um aumento significativo nos teores de compostos fenólicos, e de teores de açúcares redutores, compostos estes que podem causar aumento da cor do caldo de cana-de-açúcar e perdas para indústria prejudicando na recuperação do grão de sacarose.

Quanto a cor ICUMSA observou-se redução de 30\% da amostra controle em relação à amostra irradiada na maior dose (20 kGy) para o tratamento por radiação gama, e redução de $49 \%$ da amostra controle em relação à amostra irradiada na maior dose (20 kGy) das amostras irradiadas por feixe de elétrons, mostrando a maior eficiência desta técnica em redução de cor segundo ICUMSA de caldo de cana-de-açúcar.

A irradiação a partir de elétrons acelerados, além de causar maior redução de cor do caldo de cana-de-açúcar leva vantagens por ser um tipo de irradiação com maior produtividade $\left(\mathrm{m}^{3} / \mathrm{h}\right)$, e maior segurança segundo as regras de proteção radiológica. Podendo ser utilizada nas usinas associada a outros processos como esterilização de mosto para fermentação. 


\section{REFERÊNCIAS BIBLIOGRÁFICAS}

AGUIAR, C. L. ; BAPTISTA, A. S. ; WALDER, J. M. M. ; TSAI, S. M. ; CARRÃOPANIZZI, M. C. ; KITAJIMA, E. W. Changes in isoflavone profiles of soybean treated with gamma irradiation. International Journal of Food Sciences and Nutrition, v. 60, p. 387-394, 2009.

AGUIAR, C. L. Uso sustentável de processo livre de compostos reduzidos de enxofre (TRS) na clarificação do caldo de cana-de-açúcar decantado ou xarope na cadeia produtiva do açúcar cristal branco. Biblioteca Virtual FAPESP. Disponível em $\quad<\quad$ http://www.bv.fapesp.br/pt/pesquisa/?sort=data_inicio\&q=\%22Claudio+Lima+de+Aguiar\%22\&index=\&selected_facets=situacao_ex act\%3AEm+andamento\&selected_facets=fonte_informacao_exact\%3AProjetos+apoiados +pela+FAPESP >> Acessado em maio de 2012.

ANDRADE, L. A. B. Cultura da Cana-de-açúcar. In: CARDOSO, M. das G. (Ed.). Produção artesanal de aguardente. Lavras: UFLA, 2001.

AOAC, ASSOCIATION OF OFFICIAL ANALYTICAL CHEMISTS. Official methods of analysis. 13.ed. Washington: AOAC, 1980. p. 1015.

ARAÚJO, F. A. D. Processo de clarificação do caldo de cana pelo método da bicarbonatação. Revista Ciências e Tecnologia, v. 1, n. 1, p. 1- 6, 2007.

BEN, A. J. D.; KOIKE, G. H. A.; PASSARINI, L. C. Modelagem e simulação para o processo industrial de fabricação de açúcar e álcool. Revista Minerva, v. 3, n. 1, p. 33-46, 2006.

BIAGI, L. L. O processo da extração do caldo através da Difusão. Revista Opiniões. v. 06, n. 05, 2005. Disponível em: < http://www.revistaopinioes.com.br/aa/materia.php?id=282>. Acesso em: 07/04/2012.

BOURZUTSCHKY, H. C. C. Color formation and removal: options for the sugar and sugar refining industries: a review. Zuckerindustrie, v. 130, n. 7, p. 545-553, 2005.

BRAZ, H. Garapa boa deve vir de cana apropriada. Suplemento Agrícola - 0 Estado de São Paulo, p. 1-3, 2003.

CAMARADO. Disponível em http://box129.bluehost.com/ camarado/jp/images/static/pdf/etanolflow.pdf. Acesso em 
CAMARGO, C. A.; Conservação de Energia na Indústria do Açúcar e do Álcool: Manual de Recomendações, IPT - Instituto de Pesquisas Tecnológicas; São Paulo, 1990; p 693.

CAMARGO, A. C.; CANNIATTI-BRAZACA, S. G.; MANSI, D. N.; DOMINGUES, M.A.C.; ARTHUR, V. Efeitos da radiação gama na cor, capacidade antioxidante e perfil de ácidos graxos em amendoim (Arachis hypogaea L.). Ciência. Tecnologia de Alimentos, v. 31, p. 11-15, 2011.

CHANDRA, R.; BHARAGAVA, R. N.; RAI, V. Melanoidins as major colourant in sugarcane molasses based distillery effluent and its degradation. Bioresource Technology, v. 99, p. 4648-4660, 2008.

CHANDRA, R. Interation oh High-Energy Radiation with Matter In: Lea \& Febiger, USA: 1992, p. 69-97

CANA-DE-AÇÚCAR: ascenção e queda de uma indústria. Disponível em: $<$ http://app.crearj.org.br/portalcreav2midia/documentos/capitulo01.pdf $>$. Acesso em: 2012.

CASAGRANDE, A. A. Tópicos de morfologia e fisiologia da cana-de-açúcar. Jabuticabal: FUNEP, 1991, 180 p.

CASTRO, S. B. de; ANDRADE, S. A. C. Tecnologia do Açúcar. Recife: Universitária UFPE, 2007.

CHEN, J. C. P. Cane Sugar Handbook: a manual for sugarcane manufactures and their chemists. 11. Ed. New York: John Wiley, 1993. p. 20-82.

CHOU, C. C.; IQBAL, K.; MIN,Y. G.; GAO, D. W.; DUFFAUT, E. SAT process as a replacemant for sulfitation in mill white sugar production. International Sugar Journal, v. 108, n. 1289, p. 247-253, 2006.

CLARKE, M.A.; BLANCO, R.S.; GODSHALL, M. A. Color tests and onther indicators of raw sugar refining characteriscs. In: Proceedings of the sugar processing reaserch conference. New Orleans, p. 284-302, October 1984.

CLARKE, M.A.; BLANCO, R.S.; GODSHALL, M. A.; TO, T. B. T. Color components in sugar refinery process. In: Sugar Industry Technologist Annual Meeting, 44. Saint John, Proceedings. Martinez, 1985, p. 53-88.

CLARKE, M. A.; LEGENDRE, R. B. Qualidade da cana-de-açúcar: Impactos no rendimento do açúcar e fatores da qualidade. STAB, v. 17, n.6, p. 36-40, 1999.

CONAB-COMPANHIA NACIONAL DE ABASTECIMENTO Disponível em: < http://www.conab.gov.br/OlalaCMS/uploads/arquivos/ecf76fd96889c63b1368be80 85214377..pdf/>. Acessado em: 10/12/2010. 
CONAB-COMPANHIA NACIONAL DE ABASTECIMENTO Disponível em: << http://www.conab.gov.br/OlalaCMS/uploads/arquivos/11_08_30_13_41_19_boleti m_cana_portugues_-_agosto_2011_2o_lev..pdf >. Acessado em: 10/12/2012 CŌNSECANA. Normas operacionais do sistema de pagamento de cana-deaçúcar. Agosto. 2007.

COOPER, W.J.; TOBIEN T. The Application of Electron Beam Process in water and wastewater treatment: Fundamental and applied studies. In: USE OF IRRADIATION FOR CHEMICAL AND MICROBIAL DECONTAMINATION OF WATER, WASTEWATER AND SLUDGE, June, 1995, Vienna. Proceedings... Vienna: IAEA, 1995. (IAEA-TECDOC-1225).

COPERSUCAR. Apostila do curso de Engenharia Açúcareira - Processo de fabricação do açúcar - Parte I. centro de Tecnologia Copersucar - CTC. Copersucar, Piracicaba, 1987.

COPERSUCAR - COOPERATIVA DE PRODUTORES DE CANA, AÇÚCAR E ÁLCOOL DO ESTADO DE SÃO PAULO LTDA. Manual de controle químico da fabricação de açúcar. Piracicaba, 2001.

DAVIS, S. B. The chemistry of colour removal: a processing perspective. Sugar Milling Research Institute, University of Natal, Durban, 4041, South Africa Proc S Afr Sug Technol Ass (2001) 75 p238-336.

DELGADO, A. A.; AZEREDO CÉSAR, M. A. Elementos de tecnologia e engenharia do açúcar de cana. Vol. II. Piracicaba: Escola Superior de Agricultura Luiz de Queiroz, 1977.

DELGADO, A. A.; CESAR, M. A. Elementos de tecnologia e engenharia do açúcar de cana. ESALQ: Piracicaba, 1990. 1001p.

ENGENHO NOVO. Clarificação de xarope por flotação. TecEn Comercial: Rio de Janeiro, 2008a. 7p.

ESKIN, N. A. M.; HENDERSON, H. M.; TOWNSEND, R. J. Biochemistry of foods. Academic Press: New York, 1971. 240 p.

FELLOWS, P.J. Tecnologia do Processamento de Alimentos - Princípios e prática, 2aedição, Editora Artmed, 2006, 602p.

FENNEMA, O.R. Food Chemistry. 3th. New York: Ed. Marcel Dekker, 1996

FERMENTEC. Fenóis, amido, alumínio, fósforo e nitrogênio na cana: impacto na indústria. Fermentec News, n. 601, 2005.

FERNANDES, A. C. Atualidades. STAB, v. 17, n. 6, p. 34-35, 1999.

FERNANDES, A. P.; SANTOS, M. C.; FERREIRA, M. M. C.; NOGUEIRA, A. R.; NOBREGA, J. A. Aplicação de análise quimiométrica na diferenciação de açúcar. 
In: REUNIÃO ANUAL DA SOCIEDADE BRASILEIRA DE QUÍMICA, 27, Salvador, 2004.

FRENCH PHARMACOPEIA. X. edição. Saint-Denis: Groupe Liaisons, 2002.

GILLETT, T. R. Color and colored nonsugars. In: HONIG, P. Principles of sugar technology. Amsterdam: Elsevier Publishing Co., 1953. p. 214-290.

GODSHALL, A. M.; LEGENDRE, L. B. Phenolic content of maturing sugar cane. International Sugar Journal, v. 90, n. 1069, p. 16-19, 1988.

GODOY, O. P.; TOLEDO, F. F. Plantas extrativas: cana-de-açúcar, amendoim, girassol, mamona, mandioca, soja. Piracicaba: ESALQ, 1972, v.1.

HAMERSKI, F. Estudo de variáveis no processo de carbonatação do caldo de cana-de-açúcar. 2009. Dissertação (Mestrado) - Universidade Federal do Paraná, Curitiba.

HODGE, J. E. Chemistry of browning reactions in model systems. Journal of Agricultural and Food Chemistry, v. 1, p. 928, 1953.

HONIG, P. Principles of sugar technology. New York: Elsevier Publishing Company, v. 1, 1953.

HUGOT, E. Manual da Engenharia Açucareira. São Paulo: Mestre Jou, v.1, 1977.

ICUMSA. Method G. S. 2/3-9. The determinationof white sugar solution colour Official. International Comission for Uniform Methods of Sugar Analysis, 1994.

IBGE. Cana-de-açúcar, café e laranja aumentam valor da safra em $2,9 \%$. Disponível em: $<$ http://www.ibge.gov.br/home/presidencia/noticias/noticia_visualiza.php?id_noticia =998>. Acesso em: 20 maio 2012 .

JOSINO, A. S.; COUTINHO, M. D. H.; PESSOA, H. L. F. Caracteristica de cultivo e da nutrição. Revista: Conceitos, 133-141p. 2005.

KHAN, R.; Pure and Applied Chemistry. 1984, v. 56, p. 833.

KOBLITZ, M. G. B. Estudo de método para remoção de polissacarídeos que precipitam em cachaça. 1998. Dissertação (Mestrado) - Universidade Estadual de Campinas, Campinas.

$\mathrm{KROH}, \mathrm{L}$. W. Caramelisation in food and beverages. Food Chemistry, v. 51, p. 373-379, 1994.

LANE, H.; EYNON, L. Determinationof reducing sugar by means of Fehling's solution with methylene blue as internal indicator. Journal of the Society of Chemistry Industry, v. 42, p. 32T - 37T, 1923. 
LECLERCQ, C.; MOLINARO, M.G.; PICCINELLI, R.; BALDINI, M.; ARCELLA, D.; STACHINI, P. Dietary intake exposureto sulphities in Italy - analytical determination of sulphite-containing foodsand their combination into standard meals for adults and children. Food Additives and Contaminants, v.17, n.12, p. 979-998, 2000.

LEITÃO, M. F. F. Microbiologia de sucos e produtos ácidos. Boletim do Instituto de Tecnologia de Alimentos, Campinas, n. 33, p. 9-42, 1973.

LEITE, R. A. Compostos fenólicos de colmo, bainha, folha e palmito de canade-açúcar. 2000. Dissertação (Mestrado) - Faculdade de Engenharia de Alimentos, Campinas - SP.

LEVIT, V.; SANTOS, A. S.; FOES, A. D. R.; VANIEL, A. P.; LOUZADA, A. R.; SILVEIRA, C. M.; JARDIM, L. F.; MESKO, M. F. Preservação de pêssegos por irradiação. Universidade Federal de Pelotas - Instituto de Química e Geociências Disponível em $\quad<\quad$ http://www.sbq.org.br/ranteriores/23/resumos/11742/index.html >> Acessado em 2012.

MACHADO, R.M.D., TOLEDO, M.C.F, VICENTE, E. Sulfitos em alimentos. Brazilian Journal of Food Technology, v.9, n.4, p. 265-275, 2006.

MANTELATTO, P. E. Estudo do processo de cristalização de soluções empuras de sacarose de cana-de-açúcar por resfriamento. 2005. Dissertação (Mestrado) - Centro de Ciências Exatas e Tecnologia - Universidade Federal de São Carlos, São Carlos.

MARQUES, M. O.; MUTTON, M. A.; AZANIA, A.; TASSO JÚNIOR, L. C.; NOGUEIRA, G. A.; VALE, D. W. Tópicos em tecnologia sucroalcooleira. Jaboticabal-SP: Gráfica Multipress Ltda., 2006.

MARQUES, M. O.; MARQUES, T. A.; TASSO JÚNIOR, L. C. Tecnologia do açúcar. Produção e industrialização da cana-de-açúcar. Jaboticabal-SP: Funep, 2001.

MARKHAM, K. R. Techniques of flavonoid identification. New York: Academic Press, 1982, 113p.

MERSAD, A.; LEWANDOWSKI, R.; HEYD, B.; DECLOUX, M. Colorants in the sugar industry: laboratory preparation and spectrometric analysis. International Sugar Journal, v. 105, n. 1254, p. 269-281, 2003.

MILLER, G.L. Use of dinitrosalicylic acid reagent for determination of reducing sugars. Analytical Chemistry, v. 31, p. 426-428, 1959.

MÓNICA, C.; GARCÍA, M. T.; GONZÁLEZ G.; MAR P.; Jorge A. GARCÍA, J. A. Study of coloured components formed in sugar beet processing. Food Chemistry. v. 86, p. 421-433, 2004. 
MUÑOZ, R. B.; SANCHEZ, M. V.; UZCATEGUI, E. A.; VACA, C. F. Preservación de alimentos por irradiación. Quito: Escuela Politécnica Nacional, 1985. 350p.

NEVES, M. F.; WAACK, R. S.; MARINO, M. K. Sistema agroindustrial da cana-deaçúcar: caracterização das transcoes entre empresas de insumos, produtos e usinas In: Anais do XXXVI Congresso da sociedade brasileira de economia e sociologia rural - SOBER, Poços de Caldas, M.G., 1998.

NEVES, M. F.; CONEJERO, M. A. Sistema agroindustrial da cana: cenários e agenda estratégica. Economia Aplicada, v. 11, n. 4, 2007.

NOZELLA, E. F. Determinação de taninos em plantas com potencial forrageiro para ruminantes. 2001. Dissertação (Mestrado) - Centro de Energia Nuclear na Agricultura, Piracicaba.

OETTERER, M.; REGINATO-D'ARCE, M. A. B.; SPOTO, M. H. F. Fundamentos de Ciência e Tecnologia de Alimentos. Barueri: Manole, 2006.

OITICICA, J. E. R.; BRAS, L. M. J.; CORREIA, M. M. M. Manual de técnicas de laboratório e fabricação de açúcar de cana. Coleção Canavieira, n. 18, Rio de Janeiro, 1975.

OH, S. H.; LEE, Y. S.; LEE, J. W.; KIM, M. R.; YOOK, H. S.; BYUN, M. W. The effect of irradiation on the non-enzymatic browning reaction in aqueous model solutions. Food Chemistry, v. 92, n. 2, p. 357-363, 2004.

OH, S. H.; LEE, Y. S; KIM, J. H.; KIM, J. H.; LEE,J. W.; KIM, M. R.; YOOK, H. S.; BYUN, M. W. Effects of $\mathrm{pH}$ on non-enzymatic browning reaction during $y$ irradiation processing using sugar and sugar-glycine solution. Food Chemistry, v.94, p.420-427, 2006.

OKUNO, M.; TAMAKI, H. A novel technique for the descolorization of sugarcane juice. Journal of Food Science, v. 67, p. 236-238, 2002.

OLIVEIRA, A. C. G.; SPOTO, M. H. F.; CANNIATTI-BRAZACA, S. G.; SOUSA, C. P.; GALLO, C. R. Efeitos do processamento térmico e da radiação gama na conservação de caldo de cana puro e adicionado de suco de frutas Ciências e Tecnologia de Alimentos, v. 27, p. 863-873, 2007.

PAINTER, T. J. Carbohydrate polymers in food preservation: an integrated view of the Maillard reaction with special reference to discoveries of preserved foods in Sphagnum-dominated peat bogs. Carbohydrate Polymers, v. 36, p. 335-347, 1998.

PARANHOS, S. B. Cana-de-açúcar: cultivo e utilização. Fundação Cargil, Campinas - SP, v. 1, 1987, 431p.

PARK, Y.K.; KOO, M.H.; SATO, H.H.;CONTADO, J.L. Estudo de alguns componentes da própolis coletada por Apis melífera no Brasil. Arquivos de Biologia e Tecnologia, v.38, 1995, p. 1253-1259. 
PAYNE, J.H. Operações unitárias na produção de açúcar de cana. São Paulo, Nobel: STAB, p. 245,1989.

PHILLIPS, G. O. Radiation chemistry of carbohydrate systems. Advances in Carbohydrate Chemistry, v. 16, p. 13-58, 1961.

PODADERA, P. Estudos das propriedades do açúcar liquido invertido processado com radiação gama e feixe de elétrons. 2007. Tese (Doutorado) Instituto de Pesquisas Energéticas e Nucleares, São Paulo.

RELA P. R. Desenvolvimento de dispositivo de irradiação para tratamento de efluentes industriais com feixe de elétrons. 2003. Tese (Doutorado) - Instituto de Pesquisas Energéticas e Nucleares, São Paulo.

RIBERA, D.; JONKER, D.; NARBONNE, J.F.; O'BRIEN, J.; ANTIGNAC, E. Absense of adverse effects of sodium metabisulphite in manufactured biscuits: results of subacute (28-days) and subchronic (85-days) feeding studies in rats. Food Additives and Contaminants, v.18, n.2, p.103-114, 2001.

RIFFER, $R$. The nature of colorants in sugar cane ande cane sugar manufacture. Chemistry and processing of sugar beet and sugarcane. In: Clarke, M.A.; GODSHAL, M.A. (Eds), Elsevier Science Publishers, New York, Cap. 13, p. 186 207, 1988.

RIPOLI, T.C.C.; RIPOLI, M.L.C. Biomassa de cana-de-açúcar: colheita, energia e transporte. Saccharum, n. 17, p. 43-46, 2004.

RODRIGUES, L. P.; MORAES, M. A. F. D. Estrutura de mercado da indústria de refino de açúcar na região Centro-Sul do Brasil. Revista de Economia e Sociologia Rural, v. 45, n. 1, 2007.

ROSSITER, B. T.; SWINGLE, M. M.; Chemical Reviews.1992, 92, 771p.

RUAS, T. C. B. G. O ácido sulfuroso na sulfitação do caldo misto das usinas açucareiras. 1993. Dissertação (Mestrado) - Escola Superior de Agricultura Luiz de Queiroz, Piracicaba.

SAMPA, M.H.O.; VIEIRA, J.M.; CALVO, W.A.P.; RELA, P.R.; BORRELY, S.I. Design and construction of a pilot plant to treat wastewater and industrial effluents by electron beam accelerator. In: IAEA REGIONAL SEMINAR ON ENVIRONMENTAL APPLICATIONS OF ISOTOPES AND RADIATION TO LATIN AMERICA AND CARIBE. August 1993, Santiago, Chile. Proceedings. Vienna:IAEA, 1993.

SEaD/UFSCar. Estrutura molecular da frutose, glicose e sacarose. Disponível em << http://livresaber.sead.ufscar.br:8080/jspui/handle/123456789/535>> Acessado em 20/06/2012.

SCHWARZ, H. A. Free radicals generated by radiolysis of aqueous solution. Journal of Chemical Education, v. 58, n. 2, p. 101-105, 1981. 
SHAHIDI, F.; NACZK, Phenolics in food and nutraceuticals. Boca Raton: CRC, 2004, $558 \mathrm{p}$.

SHIMADZU APPLICATION NEWS, n. L294, Disponível em <<http://www2.shimadzu.com/applications/lc/l294.pdf〉> Acessado em 2011.

SILVA, F. C. da et al. Pequenas indústrias rurais de cana-de-açúcar: melaço, rapadura e açúcar mascavo. Brasília: Embrapa Informação Tecnológica, 2003, $155 p$.

SIMIONI, K. R.; SILVA, L. F.; BARBOSA, V. RE, F. E.; BERNARDINO, C. D.; LOPES, M. L.; AMORIM, H. V. Efeito da variedade e época de colheita no teor de fenóis totais em cana-de-açúcar. STAB, v.24, n.3, p.36-39, 2006.

SNYDER, C. H.; The Extraordinary Chemistry of Ordinary Things; 2nd Ed. John Wiley \& Sons, USA, 1995, p. 439-446.

SOUSA, J. S. I. de. (coord.) Enciclopédia Agrícola Brasileira. São Paulo: Edusp. v. 1, 1995.

SOUZA, J. Estudo da eficiência de alguns polielitrólitos utilizados na clarificação do caldo de cana. 1988. Dissertação (Mestrado) - Escola Superior de Agricultura Luiz de Queiroz, Piracicaba.

SPENCER, C. L.; MEADE, G. P. Manual del azúcar de caña. 9 ed. Montaner y Simon, Barcelona, 1967, $940 \mathrm{p}$.

STUPIELLO, J.P. A cana-de-açúcar como matéria-prima. In: PARANHOS, S. B. Cana-de-açúcar: cultivo e utilização. Campinas: Fundação Cargill, p. 30-51. 1987.

STUPIELLO, J. P. Efeito dos não açúcares. STAB, Piracicaba, v. 20, n. 3, p.10, 2002.

TAYLOR, S.L.; BUSH, R.K. Sulfitesas food ingredients. Food Technology, v.40, n. 6, p.47-52, 1986.

TELLES-FILHO, P. A. Asma Brônquica - Informações Médicas. Disponível em

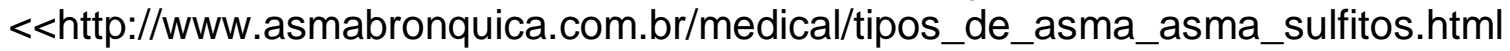
(1 of 9)>> Acessado em 2012.

TFOUNI, S. A. V.; VITORINO, S. H. P.; TOLEDO, M. C. F. Efeito do processamento na contaminação de cana-de-açúcar e derivados por hidrocarbonetos policíclicos aromáticos. Ciência e Tecnologia de Alimentos, v. 27, n. 1, p. 76-82, 2007.

USDA. USDA reallocates unused 2007 crop year cane sugar marketing allotments. <http://www.usda.gov/wps/portal/lut/p/_s.7_0_A/7_0_1OB?contentidonly=true\&co ntentid=2008/06/0162.xml>. Acesso em: 16 jun 2010. 
VAN ZELLER, A. L.; OLIVEIRA, A. J.; ZAGO, E. A. Conservação de xarope de cana-de-açúcar pelo emprego da radiação gama. STAB. Açúcar, Álcool e Subprodutos, v. 2, n. 4, p. 29-37, 1984.

VASCONCELOS, J. N. Derivados da cana-de-açúcar. STAB. Açúcar, Álcool e Subprodutos, v. 20, n. 3, p. 16-18, 2002.

VERRUMA-BERBARDI, M. R.; SPOTO, M. H. F. Efeito da radiação gama sobre o perfil sensorial de suco de laranja. Ciência e Tecnologia de Alimentos, v. 23, p. 28-32, 2003.

VILA, F. C. Identificação dos flavonóides com atividade antioxidante da cana-de-açúcar (Saccharum officinarum L.). 2006. Dissertação (Mestrado) Universidade de São Paulo, São Carlos.

WATANABE, H.; SATO, T., Changes in content and composition of sugar in molasses caused by gamma irradiation, Journal of Fermentation Technology, $v$. 58, p. 363-366, 1980.

WILSKA-JESZKA, J.; SKORUPINSKA, A. Evaluation of radurized and pasteurized fruits juices during 12 months of storage. Seszyty Naukowe Politechniki LodzkiejChemia Spozywcza, v.23, p.243-259, 1975.

WOOTON, M.; DJOJONEGORO, H.; DRISCOLL, R. The effect of $\mathrm{Y}$-irradiation on the quality of Australian rice. Journal of Cereal Science, v. 7, p. 309-315, 1988.

YAO, L. H.; JIANG, Y. M.; SHI, J. ; TOMÁS-BARBERÁN, F. A.; DATTA, N.; SINGANUSONG, R.; CHEN, S. S. Flavonoids in food and their heath benefits. Plant Food for Humam Nutrition, v.59, p. 113-122, 2004. 